\title{
Check One Box: Reconsidering Directive No. 15 and the Classification of Mixed-Race People
}

\author{
Kenneth E. Payson $\dagger$
}

\section{INTRODUCTION}

"What are you?" As the child of a Japanese mother and a White father, I have often been asked this question. ${ }^{1}$ While I am also male, heterosexual, law student, spouse, sibling, and child, this query is usually directed at my racial identity. As a mixed-race person, I am part of an ill-defined, amorphous group of persons who are increasingly becoming the subject of private and public scrutiny. As one commentator quipped, one "cannot turn on 'Oprah' without seeing a segment on multiraciality ...." The simple question "What are you?" illustrates the fundamental role race plays in defining our relationships with others. When faced with ambiguous morphology, we seek clarification of another's racial identity so that we may begin defining our

Copyright $\odot 1996$ California Law Review, Inc.

$\dagger \quad$ Law clerk to the Honorable Barbara Durham, Chief Justice, Washington Supreme Court. J.D. 1996, Boalt Hall School of Law, University of California, Berkeley. I would like to thank Professor Rachel Moran for her patience, insight, and encouragement. I would also like to thank Professors Robert Chang, Jewelle Taylor Gibbs, Angela Harris, and Marina Hsieh for their thoughtful feedback. Lastly, I would like to thank the editors and staff of the California Law Review for all their hard work. This Comment is dedicated to my wife, Monica, for her unfailing love and support.

1. I evidently appear racially ambiguous, having at various times been identified by others as Asian, Latino, American Indian or African-American. I even have a friend who for years thought I was just a White guy with a good tan. My experience is not uncommon. A mixed-race Black/Asian man described, in less neutral terms, his experience of being racially identified by others. "It was awful. We were 'niggers.' Then, we were 'Japs.' Then, we were 'Chinks,' I finally got so mad that I went, 'Make up your minds.' So they settled with 'nigger."' Theresa K. Wilkams, Prism Lives: Identity of Binational Amerasians, in RACIALLY MIXEd PEOPLE IN AMERICA 280, 296 (Maria P.P. Root ed., 1992).

See also, Jaimi Carter, "Are You Writing a Book?", in Miscegenation Blues: Vorces of Mrxed RACE WOMEN 243, 243 (Carol Camper ed., 1994) [hereinafter Miscegenation Blues] (describing the experience of a woman with a Black father and a White mother being asked, "You're not... Mexican are you?"); Claire H. Kinsley, Questions People Have Asked Me. Questions I Have Asked Myself, in MiscEgenarion BLues, supra at 113, 113-32 (listing questions a Eurasian (Chinese/White) woman has been asked including, "Your mother's Chinese? Really?" and "Who the hell do you think you're kidding, white girl?").

2. Trina Grillo, Anti-Essentialism and Intersectionality: Tools to Dismantle the Master's House, 10 BERKELEY WOMEN'S L.J. 16, 23 (1995). 
relationship to the other. ${ }^{3}$ Without such knowledge of another's race, we are left uncertain about how to define the relationship-what assumptions to make or what prejudices to reveal. ${ }^{4}$

Race not only shapes our private, personal interactions but plays a fundamental role in our public, institutional interactions as well. From its inception, the United States has divided people along racial lines. Historically, race was used to restrict or deny rights and resources to people who differed from the original American settlers of Western European ancestry. More recently, and particularly since the civil rights movement, race has been used to promote policies of inclusion, largely in the form of antidiscrimination and affirmative action legislation.

While I am able to explain that I am of both Asian and European descent to curious people on the street, I am not able to do so with respect to federal agencies. Were I to describe myself as mixed-race to a federal agency, my race would be reassigned to one of the distinct racial categories outlined in the Office of Management and Budget ("OMB") Statistical Policy Directive Number $15^{5}$

Directive No. 15 was promulgated in 1977 in an effort to standardize race classifications and definitions for all federal programs that collect or use race data ${ }^{6}$ Data collected in accordance with these racial and ethnic standards serve vital federal purposes ${ }^{7}$ and state and local

3. As sociologists Michael Omi and Howard Winant observe:

One of the first things we notice about people when we meet them (along with their sex) is their race. We utilize race to provide clues about who a person is. The fact is made painfully obvious when we encounter someone whom we cannot conveniently racially categorize-someone who is, for example, racially "mixed" or of an ethnic/racial group with which we are not familiar. Such an encounter becomes a source of discomfort and momentarily a crisis of racial meaning.

Michael Omi \& Howard Winant, Racial Formation in the United States from the 1960s TO THE 1990s 59 (1994).

4. For example, a mixed-race woman, the daughter of a White mother and a Black father, tells of being placed in an all-white section of a dormitory in college. Another student, looking at herself in a mirror, remarked, "Look at my butt. 1 have a nigger butt." Brian C. Jones, Multiracial in America: When Bias Comes from Blacks, Providence J., Feb. 11, 1988, at A1, A2.

5. Directive No. 15, Race and Ethnic Standards for Federal Statistics and Administrative Reporting, 43 Fed. Reg. 19,260, 19,269 (1978) [hereinafter Directive No. 15].

6. Id.

7. Some examples of the federal government's uses of racial and ethric data collected in accordance with Directive No. 15 are (1) enforcing requirements of the Voting Rights Act; (2) reviewing State redistricting plans; (3) collecting and presenting population and population characteristics data, labor force data, education data, and vital and health statistics; (4) establishing and evaluating federal affirmative action plans and evaluating affirmative action and discrimination in employment in the private sector; (5) monitoring access of minorities to home mortgage loans under the Home Mortgage Disclosure Act; (6) enforcing the Equal Credit Opportunity Act; (7) monitoring and enforcing desegregation plans in public schools; (8) assisting minority businesscs under minority business development programs; and (9) monitoring and enforcing the Fair Housing Act. U. S. Gen. ACct. Off., Census Reform, Early Outreach and Decisions Needed on Race and Ethinic Questions, Rep. to the Chairman, Subcommittee on Census, Statistics, and 
government interests, ${ }^{8}$ as well as the interests of private organizations and individuals. ${ }^{9}$ Foremost among these purposes is the use of racial data to track and remedy disparities in resource allocation along racial and ethnic lines. ${ }^{10}$

Directive No. 15 requires that people be categorized into one of five racial and ethnic groups: American Indian or Alaskan Native; Asian or Pacific Islander; Black; Hispanic; or White. ${ }^{11}$ However, changing demographics and changing conceptions of racial and ethnic identity have fostered concerns that these basic categories are no longer able to describe our increasingly diverse population. ${ }^{12}$

In response to growing concerns that Directive No. 15 is inadequate to describe the racial and ethnic makeup of the United States, the OMB conducted a series of public hearings to receive input for the possible revision of the Directive. ${ }^{13}$ These hearings followed in the wake of similar hearings, reviewing federal measurement of race and ethnicity, before the House Subcommittee on Census, Statistics, and Postal Personnel..$^{14}$ Among the issues raised at the latter hearings was whether current classifications were still sufficient to describe the changing population of the United States, including Arab/Middle Easterners, Native Hawaiians, Hispanics, and multiracial people. ${ }^{15}$ Not surprisingly, much of the debate centered around this last group. While the others raise the question of whether and how to classify "distinct" groups, consideration of multiracial persons directly challenges the very conception of distinct categories.

Those advocating changing Directive No. 15 to account for the increasing number of multiracial Americans are largely multiracial per-

Postal Personnel, Committee on The Post Office and Civil Service, House of RePRESENTATIVES, GAO/GGD 93-96, 12-13 (Jan. 28, 1993) [hereinafter CENSUs Reform Report].

8. State and local governments use race data to plan for schools, health and social service facilities, and other service needs. Id. at 13.

9. The private sector uses race data for business planning, marketing, and academic research. Id.

10. See id. at 12-13.

11. Directive No. 15 , supra note 5 .

12. See, e.g., Steven A. Holmes, U.S. Urged to Reflect Wider Diversity in Racial and Ethnic Classification, N.Y. TIMES, national, July 8, 1994, at 18; Ramon G. McLeod, U.S. Racial Categories Criticized by Minorities, S.F. CHRON., July 15, 1994, at A9.

13. OMB originally scheduled three hearings: Boston, July 7, 1994; Denver, July 11, 1994; and San Francisco, July 14, 1994. Advance Notice of Proposed Review and Possible Revision of OMB's Statistical Pohicy Directive No. 15, 59 Fed. Reg. 29,831 (1994) [hereinafter Advanee Notice]. To facilitate participation of Native Hawaiians in the review of classification of Native Hawaiians, OMB added a hearing in Honolulu, Hawaii on July 18, 1994. Announcement of an Additional Public Hearing on Directive No. 15, 59 Fed. Reg. 35,954 (1994).

14. Review of Federal Measurements of Race and Ethnicity: Hearings Before the Subcomm. on Census, Statistics and Postal Personnel of the House Comm. on Post Office and Civil Service, 103d Cong., 1st Sess. (1993) [hereinafter Hearings].

15. See generally id. 
sons, parents in interracial unions who advocate on behalf of their mixed-race children, and multiracial advocacy organizations. ${ }^{16}$ Privacy interests in the right to identify multiracially, the desire to increase selfesteem, and the lack of data on mixed-race persons are among the reasons offered in support of justifying such a change. ${ }^{17}$ Those opposed to such changes are largely representatives of traditional civil rights groups. They have articulated concerns that changing the status quo to acknowledge mixed-race status will negatively impact civil rights gains for their respective constituencies as people flock to the new "multiracial" category. ${ }^{18}$

Rather than evaluate the validity of the perspectives of the competing interest groups, this Comment argues that resolving the question of whether Directive No. 15 should be changed depends upon an analysis of the purposes underlying the creation of Directive No. 15 and of its usefulness in light of conteunporary social conditions. This Comment argues that the current methods for monoracially classifying mixed-race

16. See, e.g., id. at 108 (prepared statement of Susan Graham, Executive Director of Project RACE); id. at 125 (testimony of Carlos Fernández, President, Association of MultiEthnic Americans). Since the prevailing race classification paradigm is monoracial, there is not yet a standardized definition of "multiracial." However, the people who are currently challenging the monoracial paradigm and resisting monoracial labels are predominately the offspring of interracial couples. Therefore, for the purposes of this Comment, I will discuss "multiracial" or "mixed-race" persons in the context of the children of parents who identify from different racial or ethnic groups as defined in Directive No. 15. While this definition does not encompass the large proportion of Hispanic, Black, Native American, and other monoracially identified persons who may also have multiracial ancestry, it is likely that these persons self-identify and are identified by others monoracially, and therefore they do not present the same data collection problems as mixed-race persons. For a more detailed discussion of race and multiraciality, see infra Part I.

17. Hearings, supra note 14, at 130 (prepared statement of Carlos Fernández, President, Association of MultiEthnic Americans). The failure to officially recognize mixed-race status can cause self-esteem problems including having to choose the race of one parent over another when racially identifying for official purposes and, relatedly, being forced to deny the reality of one's racial heritage. See, e.g., Connie Leslie, et al., The Loving Generation: Biracial Children Seek Their Own Place, Newsweek, Feb. 13, 1995, at 72; Rogers Worthington, 'Multiracial' Census Category is Sought, CHI. TriB., July 3, 1994, at 15.

For an analysis of identity issues affecting mixed-race persons, see generally, James H. Jacobs, Identity Development in Biracial Children, in Racially MiXed People IN America, supra note 1, at 190, 190-206; Philip M. Brown, Biracial Identity and Social Marginality, 7 CHLD \& ADOLESCENT Soc. Work J. 319 (1990); Deborah J. Johnson, Racial Preference and Biculturality in Biracial Preschoolers, 38 MERRILl-PALMER Q. 233 (1992); Kathy Overmier, Biracial Adolescents: Areas of Conflict in Identity Formation, 14 J. APPLIED SOC. SCI. 157 (1990).

18. See Hearings, supra note 14, at 100-01 (prepared statement of Henry Der, National Coalition for an Accurate Count of Asians and Pacific Islanders) (arguing that it is not clear why there is a need to count multiracial persons); id. at 234 (prepared statement of Billy J. Tidwell, Director of Research, National Urban League) (voicing concerns that adding a multiracial category would "turn []the clock back" on gains made by African-Americans under affirmative action policies); id. at 239 (prepared statement of Rachel A. Joseph, Interim Executive Director of the National Congress of American Indians) (urging extensive testing prior to enacting a multiracial category, fearing that many Indian, Hispanic, and Asian people would switch to the multiracial category, thereby damaging socio-economic data for all groups). 
persons are inconsistent and arbitrary. In the face of a dramatically increasing mixed-race population that actively resists monoracial classification, the current methods undermine our ability to track and remedy disparate resource allocation along racial lines.

Before undertaking any discussion of race, we must first define the term. As we will see, "race" means different things to different people at different times. Part I, therefore, explores some of the difficulties in defining the contours of race. While this Part does not attempt to resolve what race means or ought to mean, it does seek to develop a framework for understanding the "ordinary" Ainerican concept of race-its social use and its use in law and policy.

Part II explores the evolution of the monoracial paradigm in the United States. Because the monoracial paradigm finds its roots in the social and political context of Black/White relations, this Part explores the evolution of the "one-drop" rule, which identifies persons with any known African ancestry as Black. ${ }^{19}$ While inost of the Black and White communities currently eunbrace the "one-drop" rule, for much of our nation's history, persons of mixed African and European descent occupied a status separate fronı other Blacks. Only after the abolition of slavery did the South consolidate itself behind the "one-drop" rule to minimize threats to White racial superiority. The resulting convergence of Black and mulatto interests in resisting what had become a uniform and pervasive oppression helped to forge a core non-White identity.

Part III examines the reasons why data on race and ethnicity are collected in the United States and how those data are used to track and remedy race-based discrimination. This Part explores the important role that census data serve in measuring the general demographics of the United States, and how its race data are used in comparison to race data collected by federal agencies and other organizations to track and remedy race-based discrimination. In particular, this Part looks at how the Equal Employment Opportunity Commission ("EEOC") compares employer-reported race data with census data to prove race-based employment discrimination. This Part concludes by examining the need for standardized racial categories and definitions to facilitate data comparability over time and among agencies. This need for data comparability prompted the development of Directive No. 15 .

Part IV is a historical overview of Directive No. 15, exploring the social and political context that shaped its current articulation. This Part reveals how standardized racial categories and definitions were created in an attenipt to facilitate consistent data collection and ensure the comparability of data over tinie and among federal agencies.

19. For a more complete definition of this rule, see infra notes $40-41$ and accompanying text. 
Part V evaluates the present utility of Directive No. 15 in the context of the current social climate and the uses to which race data are put. This Part examines the language and history of the Directive in relation to the social and political climate prevailing at that time, and compares the Directive's application im light of current social conditions in order to understand why the shortcomings of its current articulation are only now becoming apparent. This Part concludes that Directive No. 15's current test for monoracial classification of mixed-race persons is too vague to be implemented and, moreover, generally is not implemented, resulting in arbitrary monoracial reclassification of mixed-race persons. The resulting effect on the accuracy of race data undermines federal agencies' ability to enforce antidiscrimination laws, creating the very same problems of comparability of race data over time and among federal agencies that the Directive was intended to cure.

Part VI evaluates each of the identified shortcomings of the current system with respect to the classification of mixed-race persons and analyzes the potential effects of various solutions. Ultimately, this Part concludes that by eliciting component race information in the form of parental racial identity, the shortcomings of the current system are largely mitigated without undue complication or confusion.

Further complicating the issue are questions of whether it is even appropriate to argue for the collection of more detailed racial data at a time when an increasing number of commentators debate the role racebased classification should play in policymaking in the United States and whether we should or even could collect meaningful race data. Therefore, Part VII outlines some of the prevailing perspectives on raceconsciousness and locates my proposed changes to Directive No. 15 within the context of these often competing perspectives.

While I will address some of the concerns advanced by commentators regarding whether we should collect race information at all, the relevant question for purposes of this Comment is not whether the federal government should collect race data. Instead, assuming the federal government will continue to collect race data for the foreseeable future, this Comment examines possible effects of perpetuating the current presumption of monoraciality. While the resolution of all of the shortcomings of a government racial classification scheme is beyond the purview of this Comment, I hope to illustrate how our antidiscrimination efforts are undermined by maintaining the current methods for monoracially classifying mixed-race persons. 


\section{WHAT Is RacE?}

A discussion of mixed-race persons seems to presume that discrete races exist-a premise that may itself be faulty. How to define race and whether and how to draw racial distinctions are questions that still incite vigorous debate. The answers to these questions depend on whom you ask and at what point in history they answer. ${ }^{20}$

Although there is little agreement on how to define race, most scientists maintain that races are social rather than biological constructs. ${ }^{21}$ The Supreme Court has acknowledged the confusion surrounding the concept of "race." In Saint Francis College v. Al-Khazraji, ${ }^{22}$ a suit by an Iraqi born United States citizen who claimed that he had been denied tenure because of his Arab ancestry, the district court rejected the respondent's $\S 1981^{23}$ claim, ruling that $\S 1981$ did not apply to discrimination claims based on Arab ancestry. ${ }^{24}$ The Court of Appeals reversed, holding that althongh Arabs are considered Caucasians under the current racial classification scheme, the respondent's claim was cognizable under $\S 1981 .{ }^{25}$ The Supreme Court affimed the appellate judgment and noted the difficulty in defining "race":

There is a common popular understanding that there are three major human races-Caucasoid, Mongoloid, and Negroid. Many modern biologists and anthropologists, however, criticize racial classifications as arbitrary and of little use in understanding the variability of human beings. It is said that genetically homogeneous populations do not exist and traits are not discontinuous between populations; therefore, a popnlation can only be described in terms of relative frequencies of various traits. Clear-cut categories do not exist. The particular traits which

20. For a discussion of the historical development of racial categories in the United States, see generally OMI \& WINANT, supra note 3.

21. See, e.g., M. BANton \& J. HARwood, The RACE Concepti (1975); S. Gould, The Mismeasure of MaN (1981); Stephen Molnar, Human Variation: Races, Types, and Erhnic Groups (2d ed. 1983). But see Richard J. Herrnstein \& Charles Murray, The Bell CuRve: INTELligence AND Class Structure IN AMERICAN LifE 295-311 (1994) (arguing that different average IQ scores among ethnic groups is attributable to genetic difference).

22. 481 U.S. 604 (1987).

23. 42 U.S.C. § 1981(a) (Supp. V. 1993) provides:

All persons within the jurisdiction of the United States shall have the same right in every State and Territory to make and enforce contracts, to sue, be parties, give evidence, and to the full and equal benefit of all laws and proceedings for the security of persons and property as is enjoyed by white citizens, and shall be subject to like punishment, pains, penalties, taxes, licenses, and exactions of every kind, and to no other.

Althouglı $\$ 1981$ (a) does not refer explicitly to "race," the Supreme Court has interpreted the section to forbid racial discrimination. See Runyon v. McCrary, 427 U.S. 160, 168, 174-75 (1976) (interpreting $\$ 1981$ as forbidding racial discrimination in the making and enforcement of contracts).

24. Saint Francis College, 481 U.S. at 606.

25. Id. at 607 . 
have generally been chosen to characterize races have been criticized as having little biological significance. It has been found that differences between individuals of the same race are often greater than the differences between the "average" individuals of different races. These observations and others led some, but not all, scientists to conclude that racial classifications are for the most part sociopolitical, rather than biological, in nature. ${ }^{26}$

As the Court pointed out, attempts to locate genetic markers for race have failed because there often exists greater genetic variation within racial groups than among racial groups. ${ }^{27}$ While there are populations in geographic localities that can be distinguished from one another based on frequencies of various genetic traits, including phenotypic markers (those based on physical appearance), such traits vary on a continuum as populations geographically and biologically diverge. ${ }^{28}$ For example, while one can visually distinguish a West African person from a Chinese person, the boundary between Black and Asian cannot be clearly located as one views the gradually shifting human physical terrain of the geographic regions in between. ${ }^{29}$

Yet, as one author points out,

[w]hile the argument that physical differences alone do not define race is vitally important, it should not preclude us from investigating how race has morphological features. We can explore how racial categories are created and organized around physical characteristics; how biology and the social contexts interrelate to give meaning to these physical traits. ${ }^{30}$

Thus, while there are no genetically determinable racial groups, race has a biological component in the form of phenotype. However, the social meaning we ascribe to phenotype and the racial categories we demark are socially constructed rather than biologically inherent. ${ }^{31}$ Moreover,

26. Id. at $610 \mathrm{n} .4$.

27. See Masatoshi Nei \& Arun K. Roychoudhury, Genetic Relationship and Evolution of Human Races, 14 EVOLUTIONARY BrologY 1, 11 (1982) (noting that the genetic variation attributable to racial differences is only about 9 to $11 \%$ ).

28. See L.L. Cavalli-Sforza, The Genetics of Human Populations, Scr. AM., Sept. 1974, at 80.

29. Ian F. Haney-López, The Social Construction of Race: Some Observations on Illusion, Fabrication, and Choice, 29 HARv. C.R.-C.L. L. REv. 1 (1994).

30. Jayne Chong-Soon Lee, Navigating the Topology of Race, 46 Stan. L. REv. 747, 773 (1994).

31. Unlike sex, which has chromosomal markers of $\mathrm{XX}$ and $\mathrm{XY}$, race has no universal genetic markers. Naomi Zack, Introduction: Microdiversity vs. Purity, in AmERscan MixEd RACE: THE CULTURE OF MiCRODIVERSITY xv, xvi (Naomi Zack ed., 1995). As a geneticist has noted:

Both what constitutes a race and how one recognizes a racial difference are culturally determined. Whether two individuals regard themselves as of the same or of different races depends not on the degree of similarity of their genetic material but on whether history, tradition, and personal training and experiences have brought them to regard themselves a belonging to the same group or to different groups.... [T] here are no objective boundaries to set off one from another. 
racial categories and the rules of classification have varied from place to place and over time, adding to the sense that race is constructed, not biologically determined..$^{32}$

I will discuss "race" as "a vast group of people loosely bound together by historically contingent, socially significant elements of their morphology and/or ancestry."33 For, as Professor Haney López notes:

race must be understood as a sui generis social phenomenon in which contested systems of meaning serve as the connections between physical features, races, and personal characteristics. In other words, social meanings connect our faces to our souls. Race is neither an essence nor an illusion, but rather an ongoing, contradictory, self-reinforcing process subject to the macro forces of social and political struggle and the micro effects of daily decisions. ${ }^{34}$

Thus, phenotypic markers (e.g., skin color, hair texture, and lip, nose, and eye shapes) and cultural markers (e.g., manners of speech, dress, and outlook) are variously interpreted to inform the decision of which racial category to apply to a person.

In this sense, I will speak of groups like Black, White, Asian, Latino, and Native American as "races," not in the sense of genetically distinct racial groups but as socially constructed, uniquely American categories. I will discuss Latinos as a socially distinct racial group, contrary to the approach of Directive No. 15, which defines "Hispanic" as an ethnic rather than a racial group. ${ }^{35}$ I do this in recognition of the social reality that Latinos in the United States are generally perceived as non-White, in contrast to Directive No. 15's presumptive fiction that Latinos are White. $^{36}$ As author Paul Spickard points out, the distinction between

Paul R. Spickard, The Illogic of American Racial Categories, in Racially MrXed People in AMERICA, supra note 1, at 12, 16 (quoting J.C. KING, THE BIOLOGY of RACE 156-57 (1981)). The social construction of race has been widely discussed in legal literature. See, e.g., Neil Gotanda, $A$ Critique of "Our Constitution is Color-Blind", 44 STAN. L. REv. 1 (1991); Haney López, supra note 29; Lee, supra note 30.

32. See infra notes $40,54-68$ and accompanying text.

33. Haney-L6pez, supra note 29 , at 7 .

34. Id.

35. Directive No. 15, supra note 5 .

36. For example, both the Supreme Court and Congress have found Mexican-Americans to be victims of racial discrimination, rather than ethnic, national origin, or language discrimination. Luis A. Toro, "A People Distinct from Others": Race and Identity in Federal Indian Law and the Hispanic Classification in OMB Directive No. 15, 26 TEx. TECH. L. REV. 1219, 1248 (1995) (citing Hernandez v. Texas, 347 U.S. 475, 481-82 (1954), Keyes v. School Dist. No. 1, 413 U.S. 189, 197 (1973), and Hearings on the Home Mortgage Disclosure Act of 1975 Before the Senate Comm. on Banking, 94th Cong., 1st Sess. 1063-1120 (1975)). By defining Latinos as a racial group for purposes of this Comment, I do not mean to deny the mestizo heritage of many Latinos. Many Latinos identify as being of mixed indigenous and European heritage, and the failure of Directive No. 15 to account for mestizo identity is yet another basis for criticizing the Directive. For an in-depth analysis of Directive 
"race" and "ethnicity" is often blurred. He explains that the traditional American conception of race classification would begin with separating people into red, yellow, black, brown, and white races. ${ }^{37}$ Ethnic groups would then be subdivisions of these larger groups. ${ }^{38}$

Rather than atteinpt to distinguish "race" from "ethnicity," I will use the term "race" loosely, to encoinpass "ethnicity" to the extent that physiognomy and culture are variously interpreted to differentiate primarily Whites froin non-Whites, and various non-White groups from each other. Thus, I will discuss "inixed-race" or "multiracial" people as those whose parents racially identify themselves as belonging to different racial groups as defined by Directive No. 15. I use this definition because it is largely these persons who are asserting a multiracial identity. As we will see in Part V.B., these persons often have the unique experience of being socialized into plural racial identities. Whether the result of deliberate attempts to imbue such children with a sense of their full heritage, or the inadvertent result of exposure to and interaction with racially different parents, extended families, and communities, mixed-race persons challenge our notions of discrete races. They present us not only with their mixed faces but with their mixed experiences.

By framing my discussion of race and mixed-race within the monoracial classification scheme of Directive No. 15, I do not mean to endorse the validity of these categories. Rather, I will explore this classification scheme to denonstrate how its inability to address adequately multiracial status causes it to fail on its own terms.

II

\section{The Evolution of the Monoracial Paradigm IN THE UNITED STATES}

The American presumption of monoraciality, both socially and institutionally, finds its roots in the unique sociopolitical context of Black/White relations in the United States. African-Americans were the only sizable non-White group in the United States at the time Directive No. 15 was promulgated. ${ }^{39}$ This helps explain the Directive's presumption that the "one-drop" rule would adequately reclassify mixed-race persons. In order to explain why Directive No. 15 makes this presumption, this Section explores the evolution of the "one-drop" rule as applied to persons of African descent and the historical sociopolitical

No. 15's failure to account for mestizo identity and why Latinos should be considered a racialized minority group, see id. at 1245-51.

37. Paul R. Spickard, Mixed Blood: INTERmarriage and Ethnic Identity in TWentieth-Century AMERICA 9 (1989).

38. Id.

39. See infra Part V.A. 
forces that demanded that people be unambiguously classified as Black or White. In contrast, since race mixing outside of the Black/White context did not give rise to the same concerns that led to the application of the "one-drop" rule to persons of African descent, this Section also discusses how the "one-drop" rule has not been applied to non-Black mixed-race persons.

\section{A. Classification of African Americans: The "One-Drop" Rule}

As author Joel Williamson points out, "[i]n America we still live with the paradox that white is black. Occasionally people who are visibly white declare themselves black, and millions of Americans who are more European than African in their heritage insist, sometimes defiantly, upon their blackness." ${ }^{\text {40 }}$ This definition of Black as having any African ancestry, often called the "one-drop" rule or rule of liypodescent, ${ }^{41}$ is uniquely American; other countries have very different ways of classifying persons of mixed African and European descent. ${ }^{42}$

40. Joel Williamson, New People: Miscegenation and Mulattoes in the United STATES 2 (1980). For example, Walter White, longtime president of the NAACP, was believed to be only one sixty-fourth Black, meaning that he had a single Black ancestor six generations removed. F. JAMES DAvis, Who Is Black? One NATION's Definimon I25 (1991).

In most societies where two races have mixed, the resulting offspring usually form a buffer racial group allied with the dominant racial group. This is the case in South Africa, for example, where the "Coloureds" or mixed Black/White persons occupy a status between Whites and Africans. Id. at 90-99. There are at least seven different statuses to which mixed-race persons are assigned. Mixed-race persons may have (1) a lower status than that of either parents' racial group (Métis in Canada, the Anglo-Indians in India, Korean-Americans in Korea, and Vietnamese-Americans in Vietuam); (2) a higher status than either parent's group (Haiti and Mexico); (3) an intermediate status (South Africa); (4) a highly variable status, depending more on social class than on color (Caribbean); (5) a variable status independent of racial traits (Hawaii); (6) the same position as the lower-status group (the "one-drop" rule); or (7) the status of an assimilating minority (non-Black mixed-race in the mainland United States). Id. at 81-122.

41. The rule of hypodescent is defined as "the manner in which the superordinate racial group is kept clearly defined and in complete political, economic, and social power." Cynthia L. Nakashima, An Invisible Monster: The Creation and Denial of Mixed-Race People in America, in RACIALly MIXED PEOPLE IN AMERICA, supra note 1, at 162, 175 (citation omitted). Under this model,

[t]he metaphor is one of purity and contamination: White is unblemished and pure, so one drop of ancestral Black blood renders one Black. Black ancestry is a contaminant that overwhelms white ancestry. Thus, under the American system of racial classification, claiming a white racial identity is a declaration of racial purity and an implicit assertion of racial domination.

Gotanda, supra note 31, at 26-27 (footnotes omitted).

42. The contextualization of the American conception of Black identity is illuminated in a poem by an African American woman reflecting upon visiting Africa. 
To understand how we came to the current, peculiarly American insistence on the "one-drop" rule, it is important to understand that this has not always been the rule in our country. Regional variations in social and political conditions had previously resulted in the application of different rules for classifying persons of mixed African and European descent ("mulattoes"). ${ }^{43}$ For a good part of our nation's history, mulattoes occupied a unique status separate from that of Black slaves. ${ }^{44}$ Only when the institution of slavery was challenged and eliminated did the South consolidate itself behind the rule of hypodescent to preserve an imperiled sense of White superiority. For mulattoes and Blacks, the

\author{
crowds of children chuming up the dust \\ they chase me shouting \\ white lady! white lady! \\ ... \\ shouting \\ white lady! white lady! \\ at me \\ a nigger for 25 years
}

Faith Adiele, remembering anticipating africa, in MISCEGENATION BLUES, supra note 1, at 375, 376.

For a discussion of race classification in other countries, see generally CARL N. DEgLER, NeIther Black NoR White: Slavery and Race Relations in Brazll aNd the United STATES 103 (1986) (contrasting American race classification with the Brazilian concept of race which, as is common in much of Latin America, focuses on the many gradations between White and Black: preto, cabra, escuro, mulato escuro, mulato claro, pardo sarará, moreno, and branco de terra); George M. Fredrickson, White Supremacy: A Comparative Study in American AND SOUTH AFrican History (1981) (comparing the historical developinent of American race classification to South African race categories of White, African, Coloured, and Asian); Christopher A. Ford, Administering Identity: The Determination of "Race" in Race-Conscious Law, 82 CALIF. L. REv. 1231, 1267-85 (1994) (contrasting American race classification with those of modem India and South Africa); Anne Wilson, 'Mixed Race' Children in British Society: Some Theoretical Considerations, 35 BRIT. J. of Soc. 42 (1984) (comparing the dichotomous "Black or White" United States model of racial identity to the more flexible system of race categorization in Great Britain). For an interesting discussion of the unique situation of Whites occupying both the highest and lowest racial statuses, see Peter Simmons, "Red Legs": Class and Color Contradictions in Barbados, 11 Stud. Comp. INT'L Dev. 3 (1976) (examining the racial hierarchy in Barbados, which is characterized by an economically dominant white minority, followed by a mixed-race middle class, a Black proletariat, and a White underelass).

43. In the United States, the term "mulatto" has generally been understood to mean a person of visibly Black and White ancestry. Specifically, a "mulatto" was a person who was half black and half white. A "quadroon" was one-quarter black, an "octoroon" was one-eighth black. While most Whites did not make finer distinctions, in Louisiana, as was common in most Latin cultures, there were words for persons of even one-sixty-fourth black ancestry. WILLIAMSON, supra note 40 at xiixiii. This attention to blood quanta ultimately was misplaced, for Whites, Blacks, and Asians had been mixing far before the colonial period. In Latin America, Whites mixed with Blacks for over a hundred years before the first Whites or Blacks came to Virginia. Because both Whites and Blacks had been mixing before the settlement of North America, and since some of the first Blacks who came to North America were from Latin America and, therefore, likely of mixed ancestry, speaking of Black and White mixing is relative. Id. at xiii.

44. For the purposes of this Section only, I will speak of "mulattoes" as persons recognized as being of mixed African and European ancestry, and I will speak of "Blacks" as persons who were recognized as being "pure" Black. 
resulting convergence of interests in resisting what had becoine a singular oppression helped to forge a core, non-White identity. An exploration of the evolution of the "one-drop" rule is important $m$ order to evaluate the utility of the rule in today's social climate.

Black and White unixing in North America dates from the earliest contact among Africans and Europeans and occurred significantly in the seventeenth and early eighteenth centuries in the upper South. ${ }^{45}$ Unlike later mulattoes who were the offspring of coerced sex between White planters and their slaves, these early mulattoes were probably the offspring of White indentured servants and Blacks. ${ }^{46}$

In response, most colonies enacted laws prohibiting Black/White miscegenation and declared that the children of slave mothers would be slaves. ${ }^{47}$ Further, in order to discourage White women from mating with Black men, colonies also enacted a series of laws condemning such women and their mulatto childreu to terms of imvoluntary servitude. ${ }^{48}$ However, these laws did not cover the official status of existing free mulattoes. ${ }^{49}$ Ultimately, changing social conditions brought increasing pressure to lump free mulattoes together with enslaved mulattoes and Blacks. $^{50}$ Legislatures were prompted to draw a clear line between the increased privileges of White citizens, now free of the English monarchy, and the restricted privileges of free Blacks and mulattoes. ${ }^{51}$ By the eighteenth century, the "one-drop" rule was the law throughout much of the upper South.

Mulattoes were treated very differently in the lower South. In the upper South, mulattoes appeared early in the colonial period, in fairly large numbers, and were socially subject to the "one-drop" rule. In contrast, $m$ the lower South prior to 1850 , Whites, taking their cue from race relations in Latin America and the West Indies, clearly distinguished between the Black slave mass, whom they treated harshly, and the relatively few free mulattoes, whom they treated rather leniently. ${ }^{52}$ The more affluent free mulattoes were viewed by Whites as a third class

45. The upper South included North Carolina, Tennessee, Kentucky, Virginia, and West Virginia. See Williamson, supra note 40 , at 14.

46. Id. at 7 .

47. For example, one of the oldest colonial records recounts the fate of a White man who, in Virginia in 1630 , was scntenced "to be soundly whipped, before an assembly of Negroes and others for abusing himself to the dishonor of God and shame of Christians, by defiling his body in lying with a Negro" Id. The Virginia assembly declared in 1662 that the mulatto children of slave mothers would be slaves. Id. at 8 .

48. Id. at $8-9$.

49. Id. at 9 .

50. Id. at 13-14.

51. Id. at 13.

52. Id. at 2 . 
separate from Blacks and were often used by Whites to help control Black slaves. ${ }^{53}$

Because of the relatively few free mulattoes in the lower South and the universal institution of slavery, there was not the same need to police the color line as vigilantly as in the upper South. Indeed, some parts of the lower South rejected attempts to adopt a fractional definition of Blackness until the 1850 s, preferring instead to rely on the character and reputation of the inulatto in question to resolve any questions of whether that person should be considered Black or White. ${ }^{54}$ In other areas, classification systems arose that were finely attuned to minute differences in blood quanta. ${ }^{55}$ It is important to note, however, that both approaches represented a rejection of the "one-drop" rule which had developed in the upper South. Moreover, the "one-drop" rule was effectively rejected at the federal level in 1850 as census takers began counting mulattoes separately from Blacks. ${ }^{56}$

Thus, miscegenation between both Black and White non-free persons established an initial pool of mulattoes in the upper South during the mid-colonial period. Legal and social factors subsequently contributed to the social acceptance of the "one-drop" rule and a virtual cessation of further miscegenation by Whites. In the lower South, new admixtures of White and Black occurred largely as a result of coerced sex between slaveowners and their slaves. ${ }^{57}$ This infusion of White blood and further mating of mulattoes with Blacks resulted in a lightening of the slave mass. Despite the increasing number of slaves who were more White than Black, the tautology persisted that if one were a slave then one necessarily was Black..$^{58}$ Although variations existed in the classifi-

53. Id. at 15-16. A significant number of free mulattoes, especially in Louisiana, achievcd substantial wealth and prestige, many of them as slave-owning planters. Id. at 20 .

54. Id. at 18. For example, a judge in South Carolina in 1835 refused to rule on the Whiteness or Blackness of a free mulatto based on his fractional descent, stating that:

We cannot say what admixture of negro blood will make a colored person... . [1]t may be well and proper, that a man of worth, honesty, industry, and respectability, should have the rank of a white man, while a vagabond of the same degree of blood should be confined to Id. the inferior caste.

55. For example, Louisiana Creoles recognized distinct categories for those persons as little as one-sixty-fourth Black. Id. at 24. For a detailed discussion of the unique race classification scheme of Louisiana, see generally Virginia R. Domínguez, White BY Definition: Social Classification in Creole louisiana (1986).

56. See WILliamson, supra note 40 , at 24-25.

57. Id. at 42-56. Not surprisingly, the huge power disparity between White slaveholders and their slaves led to countless incidents of coerced sex. See id. at 42. Two of the great AfricanAmerican leaders, Frederick Douglass and Booker T. Washington, were sons of White slaveowners. Id. at 53-54.

58. As early as the time of the American Revolution, there were slaves who appeared White, "as many of the founding fathers enslaved their own mixed children and grandchildren." DAvis, supra note 40 , at $48-49$. 
cation of persons of mixed African and European ancestry, in the face of the reality that persons of largely European descent now were being enslaved, the "one-drop" rule found implicit acceptance in the world of slavery. ${ }^{59}$

The period from 1850 to 1915 represented a fundamental shift towards universal adoption of the "one-drop" rule. After 1850, Whites' intolerance of miscegenation and mulattoes in the upper South was echoed by an increasingly intolerant lower South. White society went from conditional acceptance of mulatto society to outright rejection. Faced with increasing legal and social restrictions, mulattoes went "from a position of basic sympathy with the white world to one of guarded antagonism." War and continued through Reconstruction, post-Reconstruction, and into the twentieth century. By the end of the first quarter of the twentieth century, the mulatto elite had, of necessity, allied itself almost completely with Blacks. ${ }^{61}$

Black/White mixing became virtually nonexistent after $1850 .^{62}$ It is helpful to look at the cessation of Black/White mixing in terms of opportunity and inclination. Emancipation had a great effect on opportunity. Freedom alone removed Blacks from the coercive environment of and close physical proximity to Whites. Legal segregation further limited opportunities for mixing as Blacks and Whites went to different schools, held different jobs, and lived in different neighborhoods. ${ }^{63}$ With einancipation, anti-miscegenation sentiments reached a feverish pitch, leaving both Blacks and Whites disinclined to cross the color line. ${ }^{64}$

By the end of Reconstruction, the "one-drop" rule was firmly established throughout most of the United States. ${ }^{65}$ The demise of the

59. WILLIAMSON, supra note 40 , at 73 . The science of its day helped to assuage unease with the mixed-race individual. According to contemporary scholarship, races of people were uniquely suited to their geographic origins. To mix races, therefore, was to create an "unnatural type" suited to no region, whose offspring would die out within a few generations. The occurrence of mulattoes was therefore of little concern because the problem was thought to be self-correcting. Id.

60. Id. at 62 .

61. Id.

62. Id. at 33,89 .

63. Id. at 90 .

64. Id.

65. Even with the virtually universal acceptance of the "one-drop" mle there are some communities that to this day have rejected the rule. For example, the eastern states have numerous small, isolated communities of "American Mestizos," persons of mostly European descent with Native American and/or African ancestry. DAvis, supra note 40, at 136; see also G. Reginald Daniel, Passers and Pluralists: Subverting the Racial Divide, in RACIALly Mixed PeOPLE IN AMERICA, supra note 1 , at 91, 98-102 (discussing the same group as triracial isolates). A more prominent exception are the more traditional Creoles of Color. DAvis, supra note 40 , at 58 . For a detailed discussion of the unique racial classification system of the Creoles, see generally Domínguez, supra note 55. 
mulatto category as distinct from Black removed a sore from the psyche of White southerners. Although the mulatto remained a constant reminder that White was not always distinct from Black, ${ }^{66}$ by creating the fiction that any trace of Black made a person Black, Whites could assure themselves of their separateness and "purity."

In order to discourage new mixing between Blacks and Whites, anti-miscegenation statutes were enacted $\mathrm{m}$ most states prohibiting marriages between Blacks and Whites. ${ }^{67}$ In order to enforce such laws, legislatures had to designate those who would be considered Black. Initially, legislative responses varied. Some comparatively liberal jurisdictions defmed Black persons as individuals with one-eighth or more Black blood, while others defined Blacks as those with any Black ancestry. ${ }^{68}$ By 1915, however, the "one-drop" rule had become entrenched in the United States. ${ }^{69}$ Significantly, the rule was both insisted upon by Whites, who sought to preserve the purity of their race, and embraced by persons of mixed African and European ancestry in solidarity with their darker-skinned allies. The exclusiveness of the mulatto community in the lower South of the previous century had disappeared.

By the 1920's, Blacks and mulattoes were melding into a single people. With emancipation, Blacks and mulattoes had continued mixing at a high rate. While the line between White and Black had largely been reclaimed, the line between Black and mulatto had become so indistinct that in 1920 the census counted mulattoes for the last time. After that, as far as the federal government was concerned, people of any African ancestry were singularly Black.

While the government ceased being interested in mulattoes, social scientists began investigating African American society in earnest in the 1930 s and 1940s. ${ }^{70}$ These early sociologists were interested in who was mixing with whom. Their research confirmed that Black/White mixing

66. WILLIAMSON, supra note 40 , at 95 .

67. For a summary of anti-miscegenation laws in United States history, see SPICKARD, supra note 37 , at 374-75.

68. Wirliamson, supra note 40 , at 97 .

69. "'If it is known that an individual has the least modicum of Negro blood ... then he or she is considered a suitable mate of colored persons only."' Id. at 98 (quoting Charles S. MANGUM, JR., The Legal Status of the Negro (1940)).

Moreover, it was even possible by 1900 for someone who was "pure" White to be considered behaviorally Black. While persons of known African ancestry could only be Black, Whites could become Black through moral failing. Thus, in its extreme form, the White conception of Blackness was a coucept divested from biology to extend to any conceivable connection to the Black world. Id. at 108.

70. See, e.g., EdWIN R. Embree, Brown America: The Story of A New Race (1931); E Franklin Frazier, THe Negro Family in Chicago (1932); GunNer Myrdal, AN AMERICAN Dilemma: The Negro Problem and Modern Democracy (1944). For the classic, early sociological study of this emerging African American people, see W.E.B. DuBors, THE Philadelphia Negro: A Social Study (1899). 
was virtually nonexistent. ${ }^{71}$ While it hardly needs mentioning that Whites were opposed to miscegenation with Blacks, Blacks were equally opposed to mixing with Whites because of the baneful pattern of sexual exploitation during the slavery era. Indeed, Black families were "fully as anxious about the sudden appearance of a light baby in a dark family as whites were about the appearance of a child too dark."72

While Black/White mixing had largely ceased, "internal miscegenation"-mixing across the color spectrum within the Black community-regularly occurred. By the end of the 1920's, sociologist Gustavas Steward concluded that very dark and very light Blacks were disappearing so that "'brown [was] the predominating hue." "ר? This observation is important because the broad redistribution of the European gene pool among the Black population in the absence of significant new mixing with Whites reduced-though certainly did not eliminate-the numbers of Blacks who appeared to be White. Thus, the commonality of mulatto and Black interests also encouraged the resulting commonality of appearance. While the "one-drop" rule was firmly entrenched by this time, it was being applied less frequently to Blacks who appeared to be White.

\section{B. Classification of Non-Black Mixed-Race Persons}

In contrast to the classification of mixed Black/White persons, nonBlack mixed-race persons have never been subject to the "one-drop" rule. For example, different resource allocation issues resulted in the antithesis of the "one-drop" rule as applied to Native Anericans. While the White inajority had a vested interest in classifying all persons of known African descent as Black to divest them of any advantage of Whiteness, the federal government and the White majority have always had (and still have) an interest in classifying as few persons as Native American as possible because being classified Native Aunerican can result in entitlements for mixed-race persons of Native American descent. ${ }^{74}$ Therefore, the Bureau of Indian Affairs currently recognizes as Native American only persons with one-quarter or inore Native American ancestry. ${ }^{75}$ As a result, many individuals who are considered Native

71. WILLIAMSON, supra note 40 , at 116.

72. Id. at 117. Cf. DAvIs, supra note 40 , at 3 (explaining that "being light-skinned implies illegitimacy and having an underclass white parent and is thus a disgrace in the black community").

73. Winliamson, supra note 40, at 127 (quoting Gustavas Steward, The Black Girl Passes, 6 SOC. FORCES 99, 99 (1927)).

74. Zack, supra note 31 , at $\mathrm{xv}$, $\mathrm{xvi}$.

75. Id. The "blood quantum" requirement, sometimes misapprehended as a Native American scheme to preserve bloodlines, "actually was created by white American authorities to guarantee that the United States would remain a nation-state in the European mold rather than a confederation of free tribes consisting of Indians of European bloodline." Toro, supra note 36, at 1234. For a more detailed discussion of the relationship between Native American identity and "blood quantum," see 
Americans by their tribes are classified as White by the federal government. ${ }^{76}$ Also, because of the near extermination of Native Americans, they do not pose a threat to the social order in the same way that Blacks do. Therefore, Whites do not feel a need to police the color line as vigilantly. ${ }^{77}$ Indeed, Whites often consider it fashionable to claim some Native American ancestry. ${ }^{78}$

Eurasians also are not subject to the "one-drop" rule. Historically, Whites seeking to "preserve the race" have long considered White/Asian miscegenation an abomination; ${ }^{79}$ Asian communities have likewise denounced race mixing. ${ }^{80}$ Consequently, Americans who were part Japanese, for example, were often White by default because the Japanese-American community would not have them. ${ }^{81}$ This tendency can be observed in the increasing number of celebrities of Asian descent who are not identified in terms of their race and who are thereby accorded the kind of non-race status that is usually reserved by Whites. ${ }^{82}$ Keanu Reeves, Tia Carrere, Meg and Jennifer Tilly, and Dean Cain (who, ironically, plays television's Superman, the quintessential all-American superhero) are just a few examples of the growing number of mixed Asian and White persons who are cast in non-racially identified (White) roles.

Similarly, persons of part Latino ancestry are thought of in nonracial terms. Persons such as Vanna White, Linda Carter, Raquel Welch, and Ted Williams are not socially regarded as Latino although they are of mixed White and Latino descent. ${ }^{83}$

While this is not an exhaustive treatment of the many ways in which mixed-race persons are variously classified, the discussion does demonstrate that persons of non-Black mixed-race heritage have been classi-

Terry P. Wilson, Blood Quantum: Native American Mixed Bloods, in Raclally Mixed People iN AMERICA, supra note 1 , at 108, 108-25.

76. Zack, supra note 31 , at $\mathrm{xv}$, xvi. Tribal blood quantum requirements vary from as little as $1 / 256$ to as much as one-half. Wilson, supra note 75 , at 121 .

77. SPICKARD, supra note 37 , at 331 .

78. Id.

79. For example, an editorial from the early 1920's summed up the feelings.of many White Americans:

The Japanese boys are taught by their elders to look upon ... American girls vith a view to future sex relations.... The proposed [physical] assimilation of the two races is unthinkable. It is morally indefensible and biologically impossible. American womanhood is by far too sacred to be subjected to such degeneracy. An American who would not die fighting rather than yield to that infamy does not deserve the name.

Id. at 36 (quoting Roger Daniels, Politics of Prejudice (1968)).

80. Id. at 42 .

81. Id. at 366 .

82. For a discussion of how Whites perceive their own racial identity as a non-issue, see Haney López, supra note 29, at 10. Cf. Angela P. Harris, Race and Essentialism in Feminist Legal Theory, 42 StaN. L. Rev. 581, 604 (1990) (asserting that Whites 'have the luxury of "having no color"').

83. Toro, supra note 36 , at $1258-59$. 
fied differently than those of African descent. Accordingly, the presumption that the "one-drop" rule will adequately reclassify mixedrace persons is suspect since most mixed-race persons today are not of African descent. ${ }^{84}$

Four important lessons emerge from the foregoing historical material. First, after earlier divergent treatment of mulattoes, by the time of the civil rights era, the "one-drop" rule was firmly entrenched as applied to persons of African descent. Significantly, this rule was both imposed by the dominant White social order and adopted by the Black community.

Second, miscegenation between Blacks and Whites came to a virtual standstill for nearly one hundred years, while intragroup miscegenation among persons of African descent, from the very lightest to the very darkest, distributed the European gene pool broadly among the Black population. While significant variation in skin tone still exists today, most Blacks tend toward the middle of the spectrum. Thus, while many if not most Blacks are of both European and African descent, most identify themselves, and have parents who identify themselves, as Black. This crucial difference in parental identification between Blacks with remote European ancestry who identify as Black and mixed-race persons with one White and one Black parent is central to the resolution of the classification of mixed-race persons. ${ }^{85}$

Third, the cessation of Black/White miscegenation for most of the past one hundred years can be understood in terms of both opportunity and inclination, which also explain the recent resurgence in Black/White mixing. ${ }^{86}$ The very different social context of current race mixing has important implications for the identity issues facing mixed-race children today.

Fourth, non-Black mixed-race people are not socially subject to the "one-drop" rule. Any coherent racial classification scheme must be able to account for the different ways that non-Black, mixed-race persons are socially regarded.

III

Why Race Data Are Collected and How They Are Used To TRACK AND REMEDY RaCE-BASED DisCRIMINATION

Since the first census in 1790 , the race question has appeared on every census. ${ }^{87}$ The prinary reason for establishing the census was to

84. See infra Part V.B.

85. See id.

86. See id.

87. The Constitution directs that the census be taken. U.S. CoNST. art. I, § 2, cl.3. 
collect information on electoral representation. ${ }^{88}$ From 1790 to 1840 , the census distinguished only White and Negro. ${ }^{89}$ In 1850, Negro was divided into Mulatto and Black. ${ }^{90}$ In 1860, Indian and Chinese categories were added, with Japanese added in 1870.91

Although racial and ethnic information is still collected, the data have acquired new importance with the advent of the civil rights movement. Race information has become essential in implementing court decisions involving civil rights as well as in allocating government resources to meet the needs of various racial groups that have suffered discrimination.

The decennial census, in which a wide variety of information in addition to race is collected, is the most comprehensive accounting of the United States population. The Census Bureau itself, as well as public and private organizations, make use of the data by studying the relationships among various component items of information. Not surprisingly, the analysis is often directed along racial lines, studying the relationship between race and correlates such as health, education, income, housing, and employment.

The racial data collected by the Census Bureau also support unany legislative efforts to end discrimination. The Civil Rights Act of 1964, ${ }^{92}$ the Voting Rights Act of $1965,{ }^{93}$ and the Equal Employinent Opportunity Act of $1972,{ }^{94}$ all depend upon census data for compliance and enforcement efforts..$^{95}$ Not only are relationships among the collected census data studied, but the census data serve a vital role in illuminating other race data collected by federal agencies charged with implementing antidiscrimination legislation and affirmative action laws in areas such as labor, ${ }^{96}$ housing, ${ }^{97}$ and education. ${ }^{98}$

88. Doreen S. Goyer \& Eliane Domschke, The Handbook of National Population Censuses 389 (1983).

89. Socio-Political Consequences of Racial Classification in the U.S., IntERRACIAL/NTtercultural Connection, (Biracial Family Network, Chicago, Ill.), Nov./Dec. 1988 , at 1.

90. Id.

91. Id.

92. Pub. L. No. 88-352, 78 Stat. 241 (codified as amended in scattered sections of 42 U.S.C.).

93. Pub. L. No. 89-110, 79 Stat. 437 (codified as amended in scattered sections of 42 U.S.C.).

94. Pub. L. No. 92-261, 86 Stat. 103 (codified as amended in scattered sections of 5 U.S.C. and 42 U.S.C.).

95. Census Reform Report, supra note 7, at 12.

96. The Office of Federal Contract Compliance Programs ("OFCCP") of the U.S. Department of Labor collects race data to aid enforcement of Executive Order 11246, which requires, as a condition for receipt of a Government contract, that federal contractors not discriminate on the basis of race and that larger contractors adopt affirmative action plans to promote equal employment opportunity. OFCCP compares its data to census data because the census is the "only source of such race and ethnicity data at the level of detail nceded under the Executive Order 11246 program." Hearings, supra note 14, at 283 (statement of Leonard J. Biermann, Acting Director, Office of 
Typically, federal agencies compare their own data, collected in a specific context, to more general demographic data derived from the census. If resource allocation among the agency collected racial data does not comport with expectations based on the census data, inferences of discrimination can arise. For example, the Equal Employment Opportunities Commission ("EEOC") was created to enforce laws prohibiting employment discrimination based on race, color, religion, sex, national origin, age and disability. ${ }^{99}$ EEOC's enforcement responsibilities include affirmative employment planning for agencies of the federal government and oversight of federal agency discrimination complaint processing..$^{100}$

Since 1966, the EEOC has collected, maintained, and analyzed employment data on groups protected under antidiscrimination and affirmative action statutes to assist in administration and compliance activities in both the private and federal sectors. Moreover, the EEOC has a 15-year series of employment data specifically based on the categories defined in Directive No. 15.

In order to carry out its mission, the EEOC requires that employers submit information on the racial inakeup of their workforces. While employer-reported race data alone can indicate discriminatory patterns of job assignments or promotions within an organization, proving discriminatory hiring practices requires information about the demographics of the available labor pool and/or the general population. ${ }^{101}$

Federal Contract Compliance Programs, Employment Standards Administration, U.S. Department of Labor).

97. Fair Housing and Equal Opportunity ("FHEO") of the U.S. Department of Housing and Urban Development collects racial and ethnic data as mandated by the Housing and Community Development Act of 1987 and the Fair Housing Act. FHEO compares its data with census data in order "to analyze the demograpbic cbaracteristics of these beneficiaries or potential beneficiaries against the areas from which they come." Hearings, supra note 14, at 269 (statement of Paul Williams, General Deputy Assistant Secretary for Fair Housing and Equal Opportunity, U.S. Department of Housing and Urban Development).

98. The Office for Civil Rights of the U.S. Department of Education has collected race and ethnicity enrollment data from public schools since 1968 and from postsecondary institutions since 1976. Id. at 264.

99. For example, the EEOC enforces Title VII of the Civil Rights Act of 1964, as amended, the Age Discrimination in Employment Act of 1967, as amended, the Equal Pay Act, The Americans with Disabilities Act of 1990, as amended, and Section 501 of the Rehabilitation Act of 1973. Id. at 285 (prepared statement of Tony E. Gallegos, Chairman, U.S. Equal Employment Opportunity Commission).

100. Id.

101. The Supreme Court has recognized the usefulness of statistics to help prove both disparate treatment and disparate impact discrimination under Title VII. 42 U.S.C. $\$ \$ 2000 \mathrm{e}$ to $2000 \mathrm{e}-17$ (1976). In Teamsters v. United States, 431 U.S. 324 (1977), a case involving an employer who was alleged to have been involved in a pattern and practice of employment discrimination against African Americans and Latinos, the Court endorsed the use of statistics comparing workforce data with the demograplics of the surrounding metropolitan area to prove employment discrimination. Id. at 339- 
For this comparison, census data are often used to define the demographics of the control population.

For example, if employment race data are compared with the demographics of the available labor pool and the comparison indicates that persons of certain racial groups are underrepresented among the employed, inferences of discrimination can arise. Unless employerreported data are compared with census data of the larger labor pool, discriminatory hiring practices cannot be discerned. In order to derive meaningful information, however, the data from both agencies must represent information on the same racial groups. ${ }^{102}$ Therefore, it is crucial that the same-race categories are used or that the race categories which are chosen can be reaggregated into standardized categories in a consistent manner. Moreover, since the EEOC uses these data to analyze employment trends over time (for example, to measure employer compliance), data comparability over time is also critical. ${ }^{103}$ This need for standardized racial categories and definitions led to the promulgation of Directive No. 15 in 1978.

40 n.20. The Court emphasized that the use of statistical proof was crucial for establishing a prima facie case of discrimination:

Statistics showing racial or ethnic imbalance are probative in a case such as this one only because such imbalance is often a telltale sign of purposeful discrimination; absent explanation, it is ordinarily to be expected that nondiscriminatory hiring practices will in time result in a work force more or less representative of the racial and ethnic composition of the population in the community from which employees are hired. Evidence of longlasting and gross disparity between the composition of a work force and that of the general population thus may be significant....

Id. See also Hazelwood Sch. Dist. v. United States, 433 U.S. 299, 307-08 (1977) ("Where gross statistical disparities can be shown, they alone may in a proper case constitute prima facie proof of a pattern or practice of discrimination.").

Griggs v. Duke Power Co., 40I U.S. 424, 431 (1971), established that a plaintiff must demonstrate that an employer's employee selection device has a discriminatory impact on the plaintiff's protected group. The Court has approved the use of comparative statistics to show discriminatory impact. See, e.g., Dothard v. Rawlinson, 433 U.S. 321, 330-31 (1977).

For a discussion on the use of statistics in litigation, see generally DAvID W. BARNES, STATISTICS as Proof: Fundamentals of Quantitative Evidence (1983). See also Steven N. Shulman \& Charles F. Abernathy, The Law of EQual Employment Opportunity $\mathbb{1}$ 2.04[2], at 2-17 to 232 (1990) (discussing how race statistics are used to prove disparate impact employment discrimination under Title VII); see also id. $\mathbb{1} 3.06$, at 3-65 to 3-104 (discussing how race statistics are used to prove disparate treatment employment discrimination).

102. Since the EEOC "uses Census data ... to develop estimates of the race/ethnic distribution of persons available for specific jobs... the ability to make direct comparison of data across time is critical to EEOC's comphance efforts." Hearings, supra note 14, at 286 (prepared statcment of Tony E. Gallegos, Chairman, U.S. Equal Employment Opportunity Commission).

103. Id. 
IV

DiReCTIVe No. 15

The current categories are largely the result of the activities of the Federal Interagency Committee on Education ("FICE"). ${ }^{104}$.Finding a lack of useful data on racial and ethnic groups, in June 1974 the FICE created the Ad Hoc Committee on Racial and Ethnic Definitions to develop common categories and definitions of racial and ethnic groups in order to facilitate federal collection of racial and ethnic enrollment and other educational data on a "compatible and nonduplicative basis."105 Its twenty-five members represented the federal agencies most responsible for the collection or use of racial and ethnic data. ${ }^{106}$ The Ad Hoc Committee wanted to ensure that the standardized categories would allow data collected by one agency to be used in conjunction with data from another agency. ${ }^{107}$ While the Ad Hoc Committee thought that the basic categories could be subdivided in order to accommodate individual agency needs, in order to maintain comparability it wanted to ensure that data from one basic group would never be combined with that of another at the initial data collection stage. ${ }^{108}$

In April 1975, the FICE proposed five categories: American Indian or Alaskan Native, Asian or Pacific Islander, Black/Negro, Caucasian/White, and Hispanic. ${ }^{109}$ The Ad Hoc Committee considered creating a category of "Other" to account for mixed-race people or for people who wanted to state a unique racial background. However, most committee inembers opposed the inclusion of an "Other" category, fearing that it would coinplicate results, add to costs, and only legitimately apply to a small number of people. ${ }^{110}$

OMB, the General Accounting Office ("GAO"), the Health Education and Welfare ("HEW") Office for Civil Rights, and the EEOC agreed to adopt the FICE categories for a trial period of one year in order to test the categories and determine any potential problems in their implementation. ${ }^{11}$ At the end of the test period in August 1976, the FICE made minor revisions to its definitions based on suggestions from the participating agencies. The FICE then circulated the proposed final

104. Advance Notice, supra note 13 , at 29,831 .

105. Id.

106. Hearings, supra note 14, at 218 (prepared statement of Sally Katzen, Administrator, Office of Information and Regulatory Affairs, Office of Management and Budget).

107. Id. at 43 (prepared statement of Juanita Tamayo Lott, President, Tamayo Lott Associates).

108. Advance Notice, supra note 13, at 2.

109. Report of the Ad Hoc Committee on Racial and Ethnic Definitions of the Federal INTERAGENCY Committee on Education 20 (1975).

110. Hearings, supra note 14, at 43 (prepared statement of Juanita Tamayo Lott, President, Tamayo Lott Associates).

111. Id. at 218 (prepared statement of Sally Katzen, Administrator, Office of Information and Regulatory Affairs, Office of Management and Budget). 
draft to the participating agencies for final comment. In September 1976, those final categories and definitions became effective for all racial and ethnic reporting required by the federal agencies represented on the Ad Hoc Committee.

Based on these categories and definitions, OMB drafted, for agency comment, a proposed revision of its standards and guidelines for federal statistics. On May 12, 1977, after reviewing the comments and incorporating modifications, OMB promulgated Directive No. 15-the standards for racial and ethnic classification for use by all federal agencies. ${ }^{112}$ For the first time, standardized categories and definitions were to be used for all reporting on racial and ethnic groups at the federal level.

Directive No. 15 "provides standard classifications for recordkeeping, collection, and presentation of data on race and ethnicity in Federal program administrative reporting and statistical activities."113 Notably, the Directive specifically disclaims any scientific or anthropological bases for the classifications, suggesting that government collection of racial data be viewed as an instrument of social policy, rather than an instrument of anthropological or biological research. ${ }^{114}$ The Directive stresses that the classifications should not "be viewed as determinants of eligibility in any Federal program."115 Instead, the stated purpose is "to provide for the collection and use of compatible, nonduplicated, exchangeable racial and ethnic data by Federal agencies."116

\section{$\mathrm{V}$}

\section{Evaluation of Drrective No. 15's Current Utility}

While Directive No. 15 does not limit federal agencies from collecting racial and ethnic data in greater detail, any additional racial or

112. Id.

113. Directive No. 15, supra note 5, at 19,269. The categories are defined as follows:

a. American Indian or Alaskan Native. A person having origins in any of the original peoples of North America, and who maintains cultural identification through tribal affiliations or community recognition.

b. Asian or Pacific Islander. A person having origins in any of the original peoples of the Far East, Southeast Asia, the Indian subcontinent, or the Pacific Islands. This area includes, for example, China, India, Japan, Korea, the Philippine Islands, and Samoa.

c. Black. A person having origins in any of the black racial groups of Africa.

d. Hispanic. A person of Mexican, Puerto Rican, Cuban, Central or South American or other Spanish culture or origin, regardless of race.

e. White. A person having origins in any of the original peoples of Europe, North Id. Africa, or the Middle East.

114. Id. Clearly this was the intent, since the genesis of the Directive lay in the difficulties agencies like FICE were having in tracking and remedying disparate educational opportunities and attainment along color lines.

115. Id.

116. Id. 
ethnic categories used inust be capable of incorporation back into the basic categories. ${ }^{117}$ With respect to persons of mixed racial and/or ethnic origins, Directive No. 15 provides that "[ $t]$ he category which inost closely reflects the individual's recognition in his community should be used."118 This "community recognition" test is understandable, and it probably adequately reclassified most mixed-race persons in light of social conditions extant at the time of Directive No. 15's promulgation. However, changed social conditions and conceptions of race and racial identity render this test unworkable today.

Specifically, an increasing number of mixed-race persons not of African ancestry and an emerging group of mixed-race Black persons who identify as mixed-race reveal the flaws of the "community recognition" test and its implicit reliance on the "one-drop" rule. It is not clear that the "one-drop" rule is applicable to non-Black mixed-race persons. Moreover, many mixed-race persons, including mixedBlack/White persons, are asserting their mixed-race identities and resisting monoracial classification. Consequently, mixed-race persons are often inconsistently and arbitrarily reclassified under the current scheme, which renders race data used to track and remedy race-based discrimination unreliable.

\section{A. Extant Social Conditions at Directive No. 15's Promulgation}

The civil rights era laws prohibiting race-based discrimination were enacted primarily to address the systemic, institutionalized racism affecting Blacks. Indeed, Blacks were the only sizable mimority group in the United States, constituting approximately $90 \%$ of the non-White U.S. population from 1960 through $1970 .{ }^{119}$ Therefore, race mixing was likely conteinplated only between the sizable racial population groups-Blacks and Whites.

The drafters of Directive No. 15 crafted their solution to classifying mixed-race persons in this context: "The category which most closely reflects the individual's recognition in his community should be used for purposes of reporting on persons who are of mixed racial and/or ethnic origins." 120 The presumption of monoracial identification is apparent from the language of this instruction, which takes as given that a mixed-race person will be identified monoracially by "his community." While the Directive does not make clear how to define this "community," such an issue would be moot in a Black and White world

117. Id.

118. Id.

119. See U.S. DeP't OF COMmerce, Statistical ABSTract of the United States 199413 (1994) [hereinafter Statistical ABSTRACT].

120. Directive No. 15 , supra note 5, at 1 (emphasis added). 
with an entrenched "one-drop" rule. In this context, the fact that the "community" is not defined as either the Black community or the White community is not problematic because both communities probably recognized such mixed-race persons as Black. Therefore, regardless of which community's recognition made the determination, mixed Black/White persons were likely to be categorized universally as Black in a classification scheme where the only other option was White. However, as the next Section indicates, these assumptions no longer comport with current social conditions.

\section{B. Social Conditions Today}

In contrast to the 1960 s, Blacks today make up only about half of the non-White population of the United States. ${ }^{121}$ Just since 1980, the Asian and Hispanic populations have nearly doubled. ${ }^{122}$ This growth in the non-Black minority population is even more striking when viewed in the context of the few states that account for most of such growth. For example, in 1993, Blacks made up only $16 \%$ of California's non-White population, with Asians accounting for $24 \%$ and Hispanics accounting for $58 \% .^{123}$

Today, over a quarter of the United States population is nonWhite. ${ }^{124}$ The Census Bureau projects that by the middle of the next century, the proportion of non-White persons will account for half of the United States population. ${ }^{125}$ Of the non-White population, it is estimated that the proportion of Blacks will drop to roughly one-third, Asians will account for $21 \%$, and Hispanics will account for nearly half. ${ }^{126}$ This increase in the number of non-Black minorities is tied to an increase in the number of non-Black, mixed-race persons. Moreover, after nearly a century of minimal Black/White mixing, there is an emerging generation of "new mulattoes" among whom are not only individuals with one Black and one White parent, but individuals with one Black and one non-Black/non-White parent as well (e.g., Black/Asian).

This broad range of race mixing is occurring in a social climate different from that which characterized earlier mixing, one that reflects both increased opportunity and inclination to cross racial boundaries. These conditions both help explain why intermarriage has increased

121. See Statistical ABstract, supra note 119 , at 13.

122. See id.

123. See U.S. DeP'T OF Commerce, Current Population Reports, Population Projections for States, by Age, Sex, Race, and Hispanic Origin: 1993 to 2020 xvii, tbl. E (1994) [hereinafter Population Projections].

124. See Census Reform RePort, supra note 7, at 2-3.

125. See id. at 3.

126. See Statistical Abstract, supra note 119, at 13. 
significantly since the 1960s and predict its continued increase. Moreover, they help us to understand why the socialization of the resulting mixed-race offspring is being transformed.

Annerican society has becoine increasingly accepting of racial and cultural heterogeneity, particularly since the 1960 s. When my parents married in 1965, their marriage was illegal in sixteen states, ${ }^{127}$ and antimiscegenation sentiments still ran high among many White Americans. ${ }^{128}$ My own White grandfather, upon hearing of my impending birth, said that he did not want any "Jap" kid calling him grandfather. ${ }^{129}$ It was not until 1967 that the Supreme Court held antimiscegenation laws unconstitutional in Loving $v$. Virginia, ${ }^{130}$ and removed the final formal barrier to interracial unions. ${ }^{131}$

The erosion of formal barriers among the races has correlated with declining residential, educational, and occupational segregation. These social changes facilitate interracial contact, and thereby create the opportunity for persons of different races to meet and interact. ${ }^{132}$ Some theorists maintain that intermarriage occurs particularly among a stratum of college-educated, intellectually and artistically inclined people who hold their race and ethnicity lightly and are therefore more inclined to intermarry. ${ }^{133}$

One indicator of the growing number of mixed-race people is the growing number of mixed-race marriages. According to the Census Bureau, the number of interracial married couples involving either a White or a Black spouse has grown from 310,000 in 1970 to $1,161,000$ in 1992, and their proportion of all married couples has increased from

127. At the time of Loving v. Virginia, 388 U.S. 1 (1967) (holding anti-miscegenation laws unconstitutional), sixteen states had anti-miscegenation laws: Alabama, Arkansas, Delaware, Florida, Georgia, Kentucky, Louisiana, Mississippi, Missouri, North Carolina, Oklahoma, South Carolina, Tennessee, Texas, Virginia, and West Virginia. In the previous fifteen years, fourteen states had repealed anti-miscegenation laws: Arizona, Califomia, Colorado, Idaho, Indiana, Maryland, Montana, Nebraska, Nevada, North Dakota, Oregon, South Dakota, Utah, and Wyoming. Gotanda, supra note 31, at 34 n.138. All of these states forbade marriages between Blacks and Whites, and many forbade other intermarriages including those with Mongolians, Indians, Chinese, Japanese, and Maylay. SPICKARD, supra note 37 , at 374-75.

128. A 1964 gallup poll showed that $60 \%$ of the White population approved of antimiscegenation laws. SPICKARD, supra note 37, at 293.

129. My situation was hardly unique. Especially given the dynamics of World War 1I, many American families "were initially dismayed at the thought of their sons marrying Japanese women" and often greeted such news with racial epithets. Id. at 139.

130. 388 U.S. at 1.

131. It took longer for the court to resolve custody questions involving interracial marriage. In 1984, the Supreme Court decided that race should not be a factor in custody decisions when it held that the petitioner, a White woman, could retain custody of her daughter even though the petitioner's second husband was a Black man. Palmore v. Sidoti, 466 U.S. 429 (1984).

132. SPICKARD, supra note 37, at 7, 362-63.

133. Id. at 362 (citing Milton L. Barron, Intergroup Aspects of Choosing a Mate, in THE Blending American 42 (Milton L. Barron ed., 1972)); see also Milton M. Gordon, Assimilation in AMERican LifE 224-32 (1964). 
$0.6 \%$ in 1970 to $2.2 \%$ in $1992 .{ }^{134}$ Yet these data represent only intermarriage where Blacks or Whites marry someone of a different race. Therefore, marriages between Asians and Native Americans, for example, would not be included in the data. Moreover, since the Census Bureau does not consider Hispanics to be a racial group, Latino, Chicano, and other persons classified Hispanic are currently included mostly within the White population data. Therefore, a marriage between a Latino spouse and a White spouse would not be considered a mixedmarriage. When the number of marriages between Hispanics and nonHispanics is included, the number of intermarried couples has grown from 894,000 in 1970 to $2,316,000$ in 1992 . This represents an increase in the proportion of intermarried couples from $1.9 \%$ of all married couples in 1970 to $4.4 \%$ in $1992 .{ }^{135}$

Intermarriage between Whites and those of Asian descent accounts for most interracial unions. The frequency of these unions is attributable both to the increasing desirability of Asians as sexual partners among non-Asians ${ }^{136}$ and to the tendency for resistance to intermarriage among first-generation Asian immigrants to abate in succeeding generations. ${ }^{137}$ For example, in 1970, $42 \%$ of Sansei (third-generation) Japanese-American men and $46 \%$ of Sansei woinen were married to non-Japanese. ${ }^{138}$ Chinese-American outmarriage rates have also steadily mcreased from about $10 \%$ in the 1950 s, to $13 \%$ in the 1960 s, to $18 \%$ in the 1970s. ${ }^{139}$ Filipino Americans outmarriage rates in the 1970 s were $38 \%$ for women and $19 \%$ for men. ${ }^{140}$ These factors are especially salient given that the Asian population has grown at a faster rate than any other racial group. ${ }^{141}$ If similar increases in intermarriage rates occur among succeeding generations of Asians, the number of mixed-race persons of Asian descent will likewise represent much of the growth in the mixed-race population.

Other groups exhibit similar outmarriage trends. By the third generation, the outmarriage rate for Latinos approaches $30 \% .^{142}$ Native

134. U.S. Bureau of the Census, Current Population Reports, Series P20, No. 468, Marital Status \& Living arrangements: March 1992 X (1992) [hereinafter Marital Status].

135. Id. at XI. Cf. Hearings, supra note 14, at 80 (testimony of Emerson Elliott, Commissioner, National Center for Education Statistics) (testifying that the proportion of interracial couples in the United States has grown from $2 \%$ of all married couples in 1970 to $4.5 \%$ in 1992).

136. SPICKARD, supra note 37 , at 35-93.

137. See id.

138. Id. at 59 .

139. Id. at 345 .

140. Id.

14I. Hearings, supra note 14, at 7 (prepared statement of Harry A. Scarr, Acting Director, Bureau of the Census).

142. SPICKARD, supra note $37,344-45$. 
Americans have always had high outmarriage rates of about $50 \% .^{143}$ Black/White marriages, while accounting for the fewest mixed marriages, are also increasing. The number of Black/White married couples in the United States increased almost 300\% from $1970(65,000)$ to 1992 $(246,000) .{ }^{144}$

Because the Census Bureau does not collect multiracial data, we can only infer that most of the children of interracial marriages are mixedrace. ${ }^{145}$ As of the 1980 census, there were approximately 2 million children living in multiracial households. ${ }^{146}$ Moreover, any estimates of multiracial children based on interracial inarriage data do not include mixed-race children born out of wedlock, nor do such estimates include adnlt mixed-race persons. However, it is apparent that the number of mixed-race persons is increasing and that most such persons do not fit the traditional Black/White paradigm.

In the 1990 census, almost 10 million persons used the "Other" race category. Of the 8 million write-in responses to the race question, 253,000 indicated mixed racial parentage such as "Black-White," "White-Chinese," "Multiracial," or "Interracial."147 This 253,000 figure is not an estimate of the multiracial population, but only represents that number of respondents who indicated that they were mixedrace in the write-in box. ${ }^{148}$ Some mixed-race persons attempted to identify as mixed-race by eschewing the instructions and marking more than one box. Since the census scanners are designed to read only one marked box, such a person was monoracially classified based on whichever box was marked more darkly. ${ }^{149}$ Moreover, inany more mixed-race persons may have followed the instructions to choose only one box. Census Bureau demographers therefore acknowledge that "many more would identify with mixed-race if the option were provided."150

Not only is the number of mixed-race persons growing, but mixedrace persons today, both those who have Black ancestry and those who do not, are growing up in a very different social climate than that which characterized the development of the "one-drop" rule. We have seen that race mixing between Black and White occurred frequently early in United States history. Recall that for most of the past one hundred

143. Id. at 345 .

144. Marital Status, supra note 134 , at XI.

145. See Michael C. Thomton, The Quiet Immigration: Foreign Spouses of U.S. Citizens, 19451985, in RACIALly MiXed PeOPLe IN AMERICA, supra note 1, at 64, 73-74.

146. Jewelle T. Gibbs \& Alice M. Hines, Negotiating Ethnic Identity: Issues for Black-White

Biracial Adolescents, in RACIALly MiXed PeOple iN AMERica, supra note 1, at 223.

147. Hearings, supra note 14 , at 10 (prepared statement of Harry A. Scarr, acting director,

Bureau of the Census).

148. See id.

149. Census Reform Report, supra note 7, at 28.

150. Id. at 27 . 
years, persons of mixed African and European ancestry conceived of themselves and were perceived by others as being Black. Moreover, while such persons had White ancestry, it was often generations removed. ${ }^{151}$ They were raised in households and communities that were Black and that did not have direct contact with White family members or communities. Black/White intermarriage, however, is a more recent phenomenon. Today, mixed-race children are being raised in households with racially different parents. They therefore have the opportunity to interact with racially different parents, extended families, and communities. Consequently, increasing numbers of such persons, including mixed-race Blacks, are choosing to identify multiracially. ${ }^{152}$

For example, one author writes of a part Black woman's rejection of the "one-drop" rule in a panel discussion on discrimination. She said:

I am part French, part Cherokee Indian, part Filipino, and part black. Our family taught us to be aware of all these groups, and just to be ourselves. But I have never known what I am. People have asked if I am a Gypsy, or a Portuguese, or a Mexican, or lots of other things. It seems to make people curious, uneasy, and sometimes belligerent. Students I don't even know stop me on campus and ask, "What are you anyway?"153

Another student, a light-skinned Black woman, challenged this assertion of multiracial identity by stating: "You don't have any problem. You are black."154 This feeling was echoed by other Black students who were frustrated at this challenge to the "one-drop" rule, a rule which had given them such a clear sense of their own group identity. Some students even suggested that this mixed-race woman was a traitor to her race. ${ }^{155}$ However, this mixed-race woman illustrates the fundamental problem faced by mixed-race persons. She was not denying her African heritage; she sought to embrace the full range of her heritage. To the other students' charges, she replied: "No. Not just black. I am the other things too. All of them."'156

Even in the face of pressure from both the Black and White communities for mixed-race Blacks to identify only as Black, the contemporary social context prompts some such persons to assert plural identities. Moreover, most mixed-race persons have no Black ancestry and therefore are not subject to the "one-drop" rule. ${ }^{157}$ In the absence of this

151. See DAvis, supra note 40 , at 135 .

152. SP1CKARD, supra note 37, at 338-39.

153. DAvis, supra note 40 , at 133.

154. Id. at 134.

155. Id.

156. Id.

157. See infra notes 166-168 and accompanying text. 
rule, non-Black mixed-race individuals face fewer challenges in asserting plural identities.

The decision to embrace a multiracial identity is finding support in the psychological community. Increasingly, prominent psychologists and psychiatrists are expressing the opinion that a mixed-race person who denies one parents' racial identity makes his or her own racial identity less clear. ${ }^{158}$

On the whole, we see fundamental differences in race mixing today. First, many mixed-race persons today are race mixtures that were neither contemplated nor experienced before in U.S. history. Second, mixed-race persons, including a new generation of mixed Black/White persons, are socialized in both non-White and White worlds, unlike mixed Black/White persons of earlier generations. ${ }^{159}$ Third, the result is an increasing number of persons who conceive of themselves as multiracial and who therefore actively resist inonoracial classification efforts.

Because of the continuing power of the historical approach to Black/White relations, we may be tempted to respond as did the Black students in the previous example and say to mixed-race Blacks, "No problem. You are Black." However, given the unique application of the "one-drop" rule to Blacks, simply insisting upon this historical approach would not help us reclassify the majority of mixed-race persons, who are not of African descent and for whoin the "one-drop" rule does not apply. ${ }^{160}$ It is crucial that we understand that different mixedrace persons are treated differently depending on what their component races are and who is domg the classification. "The growing numbers of mixed-race persons who may not be treated in accordance with the "one-drop" rule and who actively resist monoracial labels, are creating data accuracy problems im a classification system that holds fast to notions of hypodescent and to outdated assumptions about the demographics of this country.

\section{Application of Directive No. 15 in Light of Current Social Conditions}

At the time Directive No. 15 was adopted, the "community recognition" test was not problematic, despite its failure to define which

158. SPICKARD, supra note 37 , at 339 .

159. Relatedly, there are some biracial Black/White children who have been adopted by White parents who also actively resist monoracial classification. DAvIs, supra note 40 , at 133 . For a discussion of the relationship between the "one-drop" rule and adoption placement decisions see $i d$. at 128-32. See also generally Elizabeth Bartholet, Where Do Black Children Belong? The Politics of Race Matching in Adoption, 139 U. PA. L. Rev. 1163 (1991); Julie C. Lythcott-Haims, Note, Where Do Mixed Babies Belong? Racial Classification in America and Its Implications for Transracial Adoption, 29 HARv. C.R.-C.L. L. Rev. 531 (1994).

160. See supra Part II.B. 
community was to be used for purposes of monoracial "recognition." The near-universal acceptance of the "one-drop" rule meant that all communities would likely have recognized mixed Black/White persons as Black. ${ }^{161}$ Since the only significant population of mixed-race persons at that time were Black/White, this test probably would have both consistently and meaningfully reclassified most mixed-race persons. By "consistently" I mean that Black/White persons were likely universally reclassified Black and not White. By "meaningfully" I mean that this classification was based on the reality that such persons likely were socially regarded and regarded themselves as Black and therefore merited inclusion in race data purporting to represent the Black population.

In today's multicultural society, however, serious flaws in the community recognition test are revealed. First, the test fails to define "community" adequately. Second, even if the "community recognition" test were workable, it is not and in some instances cannot be implemented for mixed-race persons, resulting in inconsistent and arbitrary assignment to single-race categories. This inconsistency skews race data collected to track and remedy discrimination.

\section{The "Community Recognition Test" Often Cannot Be Used}

The failure of the "community recognition" test to define "community" is problematic because in today's society the racial identity of mixed-race persons is highly contextual. Social boundaries have become more fluid. Consequently, mixed-race persons may, at times, be able to identify with more than one community. However, the indeterminate racial identities of mixed-race persons can also work to their disadvantage, leaving them with no community with which to identify. In this time of shifting conceptions of race, we cannot assume that even one monoracial community representing part of a mixed-race person's component identity will consider that mixed-race person a member of that community. As one commentator noted, "[p]ossibly the most difficult issue for people of mixed heritage is that of belonging ... constantly testing the waters to see how [they are] seen, and what the perceiver's response to their perceptions might be." 162 Because of the different perspectives of different racial communities, at times "multiracial people experience a 'squeeze' of oppression as people of color and by people of color. People of color who have internalized the vehicle of oppression in turn apply rigid rules of belonging or estab-

161. See supra Part V.A.

162. Joanne Arnott, Speak Out, For Example, in MisCegenation BLuEs, supra note 1, at 264, 266-67. 
lishing 'legitimate' membership."163 In contrast to Directive No. 15's assumption that some (presumably) non-White community will recognize mixed-race persons as "one of their own," mixed-race persons often occupy a marginal status, if they are recognized at all, within minority communities.

The internalization of negative images of ourselves, our selfhatred, poor self-esteem, make our own people the Other. We shun the white-looking Indian, the "high yellow" Black woman, the Asian with the white lover, the Native woman who brings her white girl friend to the Pow Wow, the Chicana who doesn't speak Spanish, the academic, the uneducated. Her difference makes her a person we can't trust. Para que sea "legal," she must pass the ethnic legitimacy test we have devised. And it is exactly your internalized whiteness that desperately wants boundary lines... marked out and woe to any sister or any part of us that steps out of our assigned places. ${ }^{164}$

I can attest to the nrarginal status of being mixed-race, of not having a community to belong to. I grew up im a largely White workingclass neighborhood, and I used to conceive of myself as White. In fact, I did not think of myself in racial terms and thought of my race as a non-issue in the way that my White peers did. However, over time, I had experienced enough racial slurs ${ }^{165}$ to realize that "my conımunity" did not share my conception of myself.

By default I began to think of myself as Asian. However, as I began exploring my newfound "Asianness" by participating in the Asian-American community, I realized that within the Asian-American community there is often a bias against mixed-Asian people who are seen as not being "authentic." One author explains that "people have a tendency to note the characteristics which are different from their own and generalize from those qualities as they view Eurasians. Japanese people, used to looking at Asian features, looked at Eurasians and pronounced them White. Whites, used to Caucasian features, looked at the same people and pronounced them Asians." 166 This is understandable given that Whites hardly hold a monopoly on ideas of racial purity and superiority. Historically, Asians, especially Japanese, have found ideas of race mixing repugnant and would hardly recognize as Asian some-

163. Maria P.P. Root, Within, Between, and Beyond Race, in Racially MIXED People IN AMERiCA, supra note 1 , at 3,5 (emphasis in original).

164. Id.

165. By racial slurs I mean both pejoratives like, "Chink," "Jap," "Gook," "Slant," "V.C." (Viet Cong), and well-meaning, unconscious slurs like: "You speak English very well" and "Nice to meet you, Chen" (or Kim or other Asian sounding variations of Ken).

166. SPICKARD, supra note 37, at 113. 
one with the taint of White or other blood. ${ }^{167}$ Thus, resolving racial identification by deferring to community recognition is questionable when no community will recognize a mixed-race person as one of its own.

Yet, even if mixed-race persons gain acceptance into a racial community, they still may not feel that they belong. For example, a Eurasian woman who grew up in a Jewish neighborhood in Brooklyn never had an opportunity to explore her Japanese background until she went to college:

I met inore Asians my first year [in college] than I had ever known. When one Japanese-Ainerican called me on the phone to invite me to join a Japanese-American discussion group, I was very excited. I went to the group ineetings a few times, but my "white-half" began to feel uncomfortable when the others began putting down whites.... I was desperately trying to find myself as an Asian-American wornan, but I was not succeeding.... I was born half-yellow and half-white. I could not be one and not the other anymore than I could cut myself in half and still exist as a human being. ${ }^{168}$

Even Black/White mixed-race persons encounter similar problems from the African American community. One woman, whose inother was White and whose father was Black, writes poignantly about having to endure slurs from both the White and Black communities:

Do you remember when the kids used to call me "zebra"? Do you know what it meant to be called zebra? Do you know what it felt like? Well I will tell you. It hurt, it more than hurt. It penetrated my very being, it insulted my very existence... . It was in secret that I shed my appalled tears about being reduced to the stripes of a mule-like animal. Other names that I have had to endure because of my biological make-up are "half-caste," "halfbreed," "ms. peach," "yellow girl," "mixed gal," "light-skinned inama" and the list goes on. This name calling has gone on both in your community and within mine. All my life I have been burdened with being either too dark or not dark enough. ${ }^{169}$

Therefore, in contrast to the historical uniform perception of mixed Black/White persons as being Black, mixed-race persons today, includ-

167. See id. at 108. Japanese society may be even more race conscious than American society, drawing distinctions between "ordinary Japanese" who were appropriate mates, and unacceptable Japanese such as Okinawans and eta (also called burakumin), an outcast class. Id. at 94-103.

168. Id. at 116-17.

169. Loraine Mention, Letter to a Friend, in Miscegenation Blues, supra note 1, at 224, 225 26; see also DAv1s, supra note 40 , at 74-75 (explaining that vcry light skin is undesirable in the African American community); Kathy Russell, et al., The Color Complex (1992) (exploring the phenomenon of colorism in the African American community). 
ing Black/White persons, often cannot claim and are not claimed by any monoracial community. Moreover, gaining acceptance im minority communities often coines at the cost of social marginalization and ostracism. Concomitant with this marginalization is the tendency to label those who assert plural identities as "sell-outs." Such persons "are not allowed to discuss their multiraciality if they want to be included as legitimate 'persons of color.'"170 Thus, Directive No. 15's presumption that there exists a monoracial community that would "recognize" each mixed-race person as one of their own is increasingly faulty.

\section{The "Community Recognition Test" Often Is Not Used}

Mixed-race persons are reclassified monoracially in two different stages in the census data gathering process. At the first stage (data collection stage), the data reporter, whether it is the individual or a third party, is usually instructed to choose one race that "best describes" the individual. Therefore, mixed-race persons who identify monoracially or who choose not to assert their mixed-race status are funneled into one race category by choice or based on a third party's best guess. The second stage (reaggregation stage) reclassifies self-reported data from those persons who resist monoracial identification by identifying otherwise. Such resistance efforts include refusal to answer, writing in "multiracial," and checking more than one box or writing in component information. Different agencies use different methods of reclassifying such responses. Current methods of monoracial reclassification at these two stages result in unreliable data.

\section{a. The Self- vs. Other-Identification Problem}

Directive No. 15 does not specify which method of race data collection to use, self-reported or other-reported. ${ }^{171}$ Therefore, some agencies use self-reported data and others use third-party-reported data. ${ }^{172}$ For example, EEOC guidelines stipulate that employers may not directly elicit race information from einployees; they are to make their evaluation by visual inspection only. ${ }^{173}$ The practice of using observer identification was born out of the fear that asking a person's race would be offensive, that persons would be reluctant to self-identify among only the enumerated categories, and that self-identification would be too time

170. Nakashima, supra note 41 , at 174.

171. See Directive No. 15 , supra note 5.

172. The problem of third-party reported data errors are raised in Census Reform Report, supra note 7, at $12 \mathrm{n} .1$; and in Ford, supra note 42.

173. See 29 C.R.R. § 1602.13 (1995). See also EQUAL Employment OpPoRtunity Commission, Standard Form 100 1nstruction BookLet 5 (1992). 
consuming. ${ }^{174}$ Moreover, since the objective of the race data was to obtain information relating to race discrimination, observer identification was thought to be a good proxy for community perception. ${ }^{175}$ On the other hand, the Census Bureau uses self-reported data. Problems thus arise, since comparisons between EEOC data and Census Bureau data are crucial for proving racial discrimination. ${ }^{176}$

In an era when mixed Black/White persons identified themselves as Black and were identified by both the Black and White communities as Black, it did not matter whether self- or other-reported race data collection was used. However, in our increasingly diverse and phenotypically ambiguous society, third parties may have a difficult time classifying monoracial persons, let alone mixed-race persons.

For example, imagine that I take the census instructions to heart or self-identify as Japanese and check a single box on the census. My employer, for EEOC reporting purposes, however, looks me over, notes my tan complexion, black hair, and observes me speaking Spanish with Chicano co-workers. Maybe he hesitates at the slight almond cast of my eyes, but in the end he figures Chicano is a pretty good guess. In a local employment discrimmation case comparing census with EEOC data, the labor pool data counts me and others like me as Asian. However, EEOC data mclude me among the employed Hispanics, overstating those statistics and understating statistics for Asians. ${ }^{177}$

The discrepancy between self- and other-reported data is not merely hypothetical. A recent study of birth and death certificates of infants revealed that $43 \%$ of Asian and American Indian infants were classified by race differently at death than at birth. ${ }^{178}$ It is believed that third-party identification of the infants' race at death was the cause of the discrepancy. ${ }^{179}$ These examples demonstrate how differences between self- and other-reported data can arise and how such differences undermine data comparability among agencies.

174. See Hearings, supra note 14, at 294 (response to written questions submitted by Congressman Sawyer to Tony E. Callegos, Chairman, U.S. Equal Employment Opportunity Commission); Janet L. Norwood \& Deborah P. Klein, Developing Statistics To Meet Society's Needs, MONTHLY LAB. REv., Oct. 1989, at 14, 16.

175. Norwood \& Klein, supra note 174 , at 16.

176. See supra Part 111 .

177. See id.

178. See Hearings, supra note 14, at 20-21 (testimony of William M. Hunt, Director, Federal Management Issues, General Govemment Division, U.S. General Accounting Office). See also Lynn Duke, Study: Infant Mortality Rates, WASH. PosT, Jan. 8, 1992, at A9 (discussing misreporting).

179. Hearings, supra note 14, at 21 (testimony of William M. Hunt, Director, Federal Management Issues, General Government Division, U.S. General Accounting Office). 


\section{b. The Inconsistent Reclassification Problem}

As discussed earlier, an increasing number of mixed-race persons identify as mixed-race. ${ }^{180}$ There are some, like myself, who arrived at such a self-conception on their own. Others are purposefully raised in an environinent that values all parts of the person's heritage. Many of us, and many of our parents, are not content to pick one box. Such resistance efforts include refusal to answer, writing in "multiracial," checking inore than one box, and/or writing in component information. The lack of a standard method for reclassifying these mixed-race persons is another factor undermining data reliability and comparability among agencies. This Section explores some of the consequences of mixed-race persons' efforts to resist monoracial identification and the ad hoc measures used to reclassify these responses.

The 1990 census form instructed respondents to "[f]ill ONE circle for the race that the person considers himself/herself to be."181 Because the instructions stressed that only one box be checked, during the 1990 census, the Census Bureau received many calls from "[p]ersons of mixed parentage or parents of multi-racial children who wanted to report their own race or the race of their children in inore than one category." 182 One of these parents was Susan Graham, Executive Director of Project RACE, a national organization advocating for multiracial children. ${ }^{183}$ Rather than instructing Ms. Graham to use the "community recoguition" test, the Census Bureau told her that mixed-race children should take the race of their mother. ${ }^{184}$ In response to her question why they should be classified as the race of the inother only, the Census Bureau representative said to her "in a very hushed voice, "Because in cases like these, we always know who the mother is and not the father." "185 However, when Ms. Graham enrolled her son in kindergarten, she agam faced five mutually exclusive racial categories and chose to leave the race question unanswered. ${ }^{186}$ She later learned that the teacher

180. See supra Part V.B.

181. 1990 CENSUS (emphasis in original).

182. Hearings, supra note 14, at 9 (prepared statement of Harry A. Scarr, Acting Director, Bureau of the Census).

183. There are also many local interracial support groups including Interracial Family Alliance in Houston and Atlanta, Multiracial Americans of New York, Biracial Family Network in Chicago, Interracial Family Unity Network in Missouri, Cincinnati Multiracial Alliance, Multiracial Alliance of Wisconsin, and Multiracial Americans of Southern California. University groups for multiracial students include Hapa Issues Forun at the University of California at Berkeley, Students of Mixed Heritage at Williams College, and the Multiracial Group at the University of Michigan. Additionally, there are two national magazines devoted to multiracial families: New People and Interace.

184. Hearings, supra note 14, at 105-06 (prepared statement of Susan Graham, Executive Director, Project RACE).

185. Id. at 106 .

186. Id. Ms. Graham's reluctance to pick a single race category for her son was shared by my parents. As my parents enrolled me and each of my siblings in school, they consistently refused to 
was instructed to choose a race category for her son, resulting in her child being "White on the United States Census, Black at school and multiracial at home, all at the same time."187 Discrepancies like these are multiplied across the board when one considers that while Ms. Graham's school district used third-party observation to resolve the question, some school districts determine a student's race or ethnicity by that of the mother, and others use that of the father. ${ }^{188}$ Therefore, when school districts forward race data to the Office for Civil Rights of the Department of Education, their results may be incoinpatible with census data.

In Ms. Graham's case she made the effort to contact the Census Bureau in advance to resolve her questions about how to classify her son. However, many mixed-race persons choose to resolve the issue to their own satisfaction. Many used the "Other" category on the census to write in "multiracial," "biracial," "mixed-race" or other means of designating multiple racial identity. For those who gave only this information, the Census Bureau reassigned such persons based on the race of the nearest neighbor who gave the same response in the Hispanic category. ${ }^{189}$ For example, if I wrote in "mixed-race" and answered "no" to the Hispanic origin question, and my nearest neighbor were Black (as many of my neighbors are), and likewise anwered "no" to the Hispanic origin question, then I would be reassigned Black. If, on the other hand, a person wrote in her component races, she would be reassigned based on the first race listed. ${ }^{190}$ Therefore, if I were to put Japanese/White, I would be reassigned as Japanese, while if my sister were to put White/Japanese, she would be reassigned as White.

These are just a few examples of how different reclassification methods undermine data comparability. That the same persons may be counted as different races by different reporting bodies has serious implications, given the ways that interagency data comparison is used in civil rights law enforcement. Therefore, in cases where one agency uses the data of another agency to say something meaningful about its own data (e.g. EEOC and census data used to prove discrimination), we must question how reliable the data are.

identify us monoracially and left the race question unanswered. Unknown to us at the time, we were reclassified based on our first names. My brother Michael and I were classified White, while my sisters, Akiko and Junko, were classified Asian. It was not until we entered high school that we learned that we were classified as different races, when my brother and I, because of a mandatory bussing program in our school district, were assigned to a different school than my sisters.

187. Id.

188. Hearings, supra note 14, at 28 (prepared statement of William M. Hunt, Director, Federal Management Issues, General Government Division, U.S. General Accounting Office).

189. CENSUS REFORM REPORT, supra note 7, at 28.

190. Hearings, supra note 14, at 10 (prepared statement of Harry A. Scarr, Acting Director, Bureau of the Census). 
This inconsistent reclassification creates comparability problems similar to those that prompted the development of Directive No. 15. Because Directive No. 15 has not kept pace with changing social conditions, the same person can be classified differently by different agencies.

\section{c. The Arbitrary Reclassification Problem}

This Section looks at a problem related to differences in classification: the arbitrary reclassification of mixed-race persons. Reclassification methods do not attempt, and therefore do not accomplish, the task of reclassifying mixed-race persons in a meaningful manner. Meaningful reclassification would include a mixed-race person in a monoracial group because that person is likely to be treated as a member of that monoracial group. In this context it is clear the various reclassification methods used by agencies (mother's race, nearest neighbor, first race listed, and so on) were adopted as administratively expedient without determining whether it makes sense to include mixed-race persons in monoracial categories based on these criteria.

One consequence of arbitrary reassignment is that mixed-race persons may be counted as White for data collection purposes, ${ }^{191}$ yet be treated in the workplace as though they were minorities, thereby masking incidents of discrimination. To understand how arbitrary reassignment can serve as a cover for discriminatory behavior, it is useful to look at the race classification scheme for traffic violations in Fairfax County, Virginia.

In Fairfax County there are only two race classifications for purposes of traffic violations: White and Black, where anyone who is not Black is White by default. ${ }^{192}$ An Asian Indian petitioner who unsuccessfully challenged his traffic ticket also was rebuffed in his attempt to change his racial classification from White to Asian Indian. ${ }^{193}$ The petitioner made the point that a Fairfax County police officer could issue two traffic tickets to African Americans, ninety-eight tickets to other

191. We have seen how this happens in the case of the census where a mixed-race person's mother is White, his nearest neighbor is White, or he lists White first when cataloguing his component racial information, depending on the reclassification method utilized. See supra notes 189-190 and accompanying text. Arthur A. Fletcher, Chairperson, U.S. Commission on Civil Rights, pointed out the potential for masked discrimination when he noted that we do not know "how many people classify themselves as white under the present system, [but] because they are multiracial, may nevertheless encounter discrimination because others identify them as minorities"). Hearings, supra note 14, at 258 (prepared statement of Arthur A. Fletcher, Chairperson, U.S. Commission on Civil Rights).

192. Robert P. Singh, Everything is Black or White in Fairfax County, WaSH. T1MEs, Sept. 27, 1993, at C2.

193. Id. 
persons of color and "be on record as having ticketed minority persons only $2 \%$ of the time." 194

Likewise, one can see how classifying multiracial people as White can distort race-based discrimination statistics if such mixed-race persons are not treated as though they were White. Returning to the employment discrimination context, assume that mixed-race persons are classified as White, yet are treated as though they were minorities. The statistics representing the minority population group would thus understate the degree of discrimination since a portion of persons (mixedrace classified as White) would be counted among the majority reference group. Hence, the discrimination claims of minorities would be offset by inclusion of mixed-race persons as White who will statistically serve as evidence of similar discrimination against "Whites."195

The corollary problem is presented by mixed-race persons who are counted as minorities but treated as though they were White. This phenomenon should cause us to question the wisdom of the current classification scheme, for to classify as minorities persons who are socially regarded as White not only understates the discrimination rates against minorities, but in a time when minority group membership can result in entitlements (due to affirmative action), this phenomenon finds such minority-group-based allotments distributed to persons who may be functionally White.

We have already seen how some persons of mixed Asian/White descent are accepted by the media, and hence presumably by society in general, as White (or at least "White enough"). We have also seen how it is not at all uncominon for persons of very remote African ancestry to claim that they are Black. Should mixed-race persons who look White and are treated as White by society be counted as members of their minority heritage group?

Take, for example, law firm hiring. Law firms are not immune to the increasing social pressure to diversify their workforces. Indeed, those who fill out National Association of Law Placement ("NALP") forms for law school placement offices are expected to give figures on attorney hiring by race. Thirty years after Title VII, there are still comparatively few minority lawyers in the more prominent American law firms, and those few minority lawyers are largely among the associate

194. Id.

195. Compare one commentator's observation that including Latinos as White will create an illusion that the disparity in income and other measures of community vitality between the majority population and the African-American community is smaller than it is in reality, because the presence of persons in the "White" sample who do not in reality enjoy the societal benefits of "White" status will skew results.

Toro, supra note 36 , at 1252. 
ranks. ${ }^{196}$ Therefore, there is continued pressure for law firms to hire minority lawyers.

Inroads are being made by minority lawyers, but what do we know about the nature of those hires? Are the minority attorneys hired representative of the minority law students on the job market? Or, as I will suggest, are those persons counted as minority hires disproportionately part-White? Since there are no data, I can offer only my own observations.

When I was interviewing with law firms during my second year of law school, I did not openly identify my race, yet my work with the Asian Law Journal and with the Asian Pacific American Law Students Association probably resolved any questions potential employers may have had about my racial background. Perhaps this explains why I was so often interviewed by minority lawyers in firms that were predominantly White. I iminediately noticed a striking tendency anong those lawyers of color: the surprising lack of color.

In response to my questions about minority representation among the attorney ranks, one attorney-a blond-haired, blue-eyed womanbegan counting off minority lawyers, beginning with herself as AfricanAmerican. In another firm, the lone minority lawyer was of partial Mexican descent. Understandably, as the market opens up to persons of color, law firms apparently will seek minorities who are more palatable to themselves and to their predominantly White clients. To the extent possible, they would likely hire minorities who do not look or act too differently from Whites. A mixed-race person who has been raised by a White parent will not only probably physically look more White but be able socially to act more White as well.

I wish to stress that I do not challenge these persons' self-identity as persons of color; I am glad to see their presence, as they do represent inroads in minority hiring. And, I must admit, I have likely benefited from employers' ability to claim me, in good faith, as a minority hire. Yet, if part-White persons represent a disproportionate number of minority hires, then how much more dismal is the picture of minority hiring with respect to the majority of minority persons who are not mixedrace? Has a person who has a White parent suffered the kind of disadvantage that we presume monoracial minorities have suffered? Or, is a part-White person not only visually and behaviorally more palatable, but also privy to the social ties and important networks via her White parent?

In the absence of data on multiracial persons, we can only guess at whether and to what extent multiracial persons are or are not victims of discrimination. Therefore, we can only guess at which of a mixed-race

196. See, e.g., Ann Davis, Survey: Boston Firms Lag in Minority Hiring, NAT'L L.J., Jan. 1, 1996, at $\mathrm{A} 9$ (listing law firm minority hiring by city nationwide). 
person's component races would be the more meaningful reclassification. Simce we have seen that persons of different race mixtures may be reclassified differently by society, there may not be a single method that will result in meaningful reclassification for all the various combinations of mixed-race persons. Moreover, in the absence of data on mixed-race persons, we do not know whether mixed-race persons' treatment comports with the treatment of one of their component racial groups.

Thus, not only does arbitrarily folding multiracial people back into single-race categories skew data used to track discrimination, but by not collecting data on multiracial people we are unable to determine whether and to what extent multiracial persons are the victims of discrimination. We therefore are unable to determine how to meaningfully reclassify such persons or if such reclassification is even advisable.

\section{VI}

Potential Solutions to Directive No. 15 's CURRENT SHORTCOMINGS

We have seen that Directive No. 15's current means for reclassifymg mixed-race persons is problematic on its face because of the assumptions it makes about the racial makeup of mixed-race persons and about the existence of a stable, uniform community perception of such persons. These assumptions can result in inconsistent and arbitrary monoracial reclassification of mixed-race persons. These results stem from three methodological problems in the current reclassification scheme: (1) the utilization of both self- and other-reported data; (2) mconsistent classification criteria among agencies; and (3) exclusive reliance on arbitrary monoracial classification.

The number of multiracial persons may have been small enough at one time to tolerate distortions of data used to track and remedy discrimination. Indeed, one of the reasons the federal government did not adopt a means of identifying mixed-race persons was precisely because of the assumption that the number of such persons would be small. ${ }^{197}$ Today, however, the increasing number of mixed-race persons in the United States makes the continuation of such imprecise data collection practices questionable. ${ }^{198}$

The imconsistent and arbitrary reclassification of mixed-race persons undermines the accuracy and comparability of race data used to track and remedy race-based discrimination. Because the crucial failing is the imconsistent and arbitrary reclassification of mixed-race persons, the solution lies in promoting consistent and meaningful reclassification,

197. Hearings, supra note 14, at 43 (prepared statement of Juanita Tamayo Lott, President, Tamayo Lott Associates).

198. See supra Part V.B. 
if such a thing is possible. Without the collection of multiracial data, we cannot determine whether it is possible to meaningfully use monoracial classifications for mixed-race persons. This Part examines both the inconsistency problem and the arbitrariness problem, and evaluates potential solutions to each, concluding that the only way to remedy these shortcomings is to collect discrete multiracial data.

\section{A. Self-vs. Other-Identification Revisited}

Because the utilization of both self- and other-reported data leads to data comparability problems, the solution lies in choosing one method. The question is whether choosing only one method is feasible.

\section{All Other-Identification}

Utilization of self-reported data is fairly recent in the history of U.S. race data collection. It was not until the 1960 census that selfreported data were extensively used. ${ }^{199}$ Prior to 1960 , census enumerators collected race data by observation. ${ }^{200}$

An argument can be made that to the extent that race data are used to track and remedy race-based discrimination, the crucial data should reflect not how a person self-identifies, but rather how she is perceived by society in general. Particularly since racial identity is contextual, other-reported identity may be more stable, reflecting broad social consensus on racial classification.

While this argument may have been defensible in an era when people were generally recoguizable as either Black or White, in today's racially diverse and increasingly mixed population, third parties are increasingly engaged in a guessing game with respect to monoracially classifying various "brown" people. We have already seen that third parties are increasingly unable to classify persons accurately when their choices are limited to discrete monoracial categories. Therefore, asking third parties to guess whether a person is mixed-race, and if so, what the person's component races are, is asking an impossible task. This suggests that adopting an all other-identification scheme is not workable.

While agencies that use third-party reported data have raised legitimate issues relating to privacy concerns if employees must report their racial identification at the workplace, ${ }^{201}$ self-reported data are not necessarily antithetical to these concerns. Since these concerns can likely be safeguarded adequately, ${ }^{202}$ and since third-party reported data

199. GOYER \& DOMSCHKE, supra note 88, at 398.

200. See id. at 389-98.

201. See supra note 174 and accompanying text.

202. See infra notes 204-207 and accompanying text. 
is of increasingly questionable accuracy, adopting across-the-board third-party reported data is not advisable.

\section{All Self-Identification}

Unlike other-reported data, self-reported data can yield information on both social perception and on individual identity. It is not necessary to elicit third-party or social perception data directly because such information is communicated in other ways. If we collect discrete, self-identified data on mixed-race persons, such data could be compared to monoracial data to determine whether such mixed-race persons are treated, and therefore are perceived to be, members of monoracial groups. For example, if mixed Black/White persons are allowed to identify as mixed-race, it is not problematic if employers perceive such persons as Black, for comparison of Black/White employment data with Black employment data should reveal similar employment trends, which in turn would allow us to infer that mixed Black/White persons are perceived by employers as Black. On the other hand, if we find that mixed Black/White persons' employment patterns more closely resemble White employments patterns, we may realize that reaggregating mixed Black/White data with Black data only undermines data accuracy.

Moreover, under a disparate impact analysis, an employer's discriminatory intent is not necessary to find a Title VII violation. ${ }^{203}$ Therefore, the relevant analysis is not whether the employer intends to discriminate against a certain racial group, but rather whether the employer does discriminate. For example, using my earlier hypothetical, now assume that the employer believes that I am Latino, ${ }^{204}$ likewise believes that other White/Asian persons are Latino, and discriminates against Latinos. Then the fact that the employer is mistaken with respect to the racial identity of mixed White/Asians is not relevant. What would be relevant is that White/Asian persons were being discriminated against. By using self-reported data exclusively, we will eliminate the discrepancy that arises from incorrect third-party guesses, while preserving the underlying purposes for such data collection-to track and remedy discrimination.

While the EEOC has expressed concern that directly eliciting race information from employees would intrnde harmfully on employees' privacy, such paternalistic concerns may be exaggerated in an era when we regularly report racial information and understand that it is used to further antidiscrimination efforts. The EEOC's presumption that em-

203. In Griggs v. Duke Power Co., 401 U.S. 424 (1971), Chief Justice Burger writing for the majority noted that "Congress directed the thrust of the Act [Title VII] to the consequences of employment practices, not simply the motivation." Id. at 432.

204. See supra text accompanying note 177. 
ployee privacy interests preclude self-reported data collection does not comport with the experience of other federal agencies that have developed self-reporting methods that take into account privacy concerns. For example, lenders are required to report race information about inortgage applicants in order to monitor compliance with federal statutes that prohibit lenders from discriminating against applicants on the basis of race. ${ }^{205}$ Applicants are requested to provide race information and are informed that the information is sought in order to monitor lender compliance with antidiscrimination legislation. ${ }^{206}$ Currently, applicants who do not wish to self-report are then assigned a race designation based on observation. ${ }^{207}$ Privacy concerns could be safeguarded further by allowing persons to report racial information anonymously. While some individuals may refuse to self-identify, to the extent that we are able to uniformly implement self-reporting of race data, we will eliminate the inconsistency that can result from faulty third-party guesses. Moreover, some argue that classifying by visual inspection intrudes upon, rather than protects, individual privacy concerns. ${ }^{208}$ Therefore, by universally adopting self-identification, we not only improve data consistency but also place the exercise of privacy interests back into the hands of the individual.

\section{B. Inconsistent Reclassification Revisited}

Reclassification provides another source of data unreliability because different methods are used by different data collection bodies. ${ }^{209}$ Resolving this problem simply requires choosing a single method to be used by all agencies. This Section evaluates several possible reclassification methods on the basis of their ability to address the problems of inconsistency and arbitrariness.

\section{Using Either the Mother's or the Father's Race}

Earlier we saw the problem Ms. Graham encountered when asked to report the race of her son on the census. ${ }^{210}$ She was instructed to list her race as the mother (White) for her mixed Black/White child. Adopting this standard of fixing the race of a child as that of one of its parents would promote consistency to the extent that Ms. Graham's son would be reported as White on the census and also at school. However,

205. Home Mortgage Disclosure, 12 C.F.R. § 203.4 (1995).

206. Id. at pt. 203, app. B.

207. Id.

208. Hearings, supra note 14, at 130 (prepared statement of Carlos Fernández, President, Association of MultiEthnic Americans) (arguing that visual inspection violates individuals' privacy rights).

209. See supra Part V.C.2.b.

210. See supra notes $183-187$ and accompanying text. 
it would not promote consistency in reclassifying mixed Black/White persons as a group.

For example, if Ms. Graham's brother (presumably White) married Mr. Graham's sister (presumably Black) then their children would be classified as Black under a classification scheme that classifies mixedrace children by the race of the mother. Cousins with essentially the same Black and White ancestry would be classified differently from each other. Therefore, simply instituting a rule requiring the use of the mother's or father's race will not achieve the goal of consistent classification for mixed-race persons.

\section{Explicit Hypodescent Standard}

Given that Directive No. 15's unstated premise for monoracial reclassification of mixed-race persons is the rule of hypodescent (the "one-drop" rule), ${ }^{211}$ one could argue that the easiest response would be to make that assumption explicit. This would require articulating a hierarchy of racial subordination and stating the rule that persons of multiple descent should identify racially with the more subordinated compouent racial group. Under this model a White person would be a person with White parents; a person with only one White parent would identify with the race of the non-White parent; and a person with two non-White parents would identify with the more subordinated racial group.

This approach most closely comports with social reality. Given the internalization of the rules of racial subordination, most persons raised in the United States would have little trouble articulating the hierarchy of racial subordination in this country. To the extent that society understands that different racial groups have suffered different levels of oppression, this approach could conceivably reflect societal treatment of mixed-race persons.

However, this approach sets the dangerous precedent of officially recognizing and codifying racial hierarchy. While academics and policy makers may be able to distinguish between the social reality of racial subordination and the pseudoscience of genetically-cletermined racial hierarchy, society at large may not grasp such a distinction. Therefore, such an approach runs the risk of appearing to lend credence to notions of White supremacy. Perhaps the political unpalatability of this solution explains why it is not made explicit, although it often operates de facto. ${ }^{212}$

211. See supra Part V.B.

212. This reassignment based on the hierarchy of racial subordination is not unprecedented. At the University of California, Berkeley School of Law (Boalt Hall), the admissions application contains a racial identification question. The enumerated categories are monoracial, and there is an "Other" 
However, this solution, if adopted, would only resolve the inconsistency problem. It is true that adopting a single standard will alleviate the reliability problems caused by inconsistent reclassification and may alleviate the arbitrariness problem to the extent that persons are treated in accordance with the rule of hypodescent. However, because nonBlack mixed-race persons are not subject to the rule of hypodescent, ${ }^{213}$ simply codifying hypodescent will not fully address the arbitrariness problem.

\section{Arbitrary Reclassification Revisited}

The methodological problems stemming from having different data reporters (the self- versus other-reported identity problem) and having different reclassification methods (the inconsistency problem) can be resolved by choosing single standards to ensure uniformity of data among agencies. Yet the purpose of achieving uniformity is frustrated if we simply achieve uniformly arbitrary information. For example, we may adopt a self-reported standard which reassigns a mixed Asian/White person as Asian and achieve consistency among agencies; nevertheless, if an Asian/White person is not treated as an Asian in society, we have failed to remedy the arbitrariness problem.

If we are to continue the practice of reclassifying mixed-race persons monoracially then we must ensure that such reclassification, to the extent possible, reclassifies mixed-race persons into monoracial categories which most closely match their perception and treatment by society. The only way to determine this is first to collect discrete data on mixedrace status. The following Sections evaluate two proposals to collect multiracial data: a sole multiracial category and a multiracial category that also elicits parental racial data.

\section{Sole Multiracial Category}

Project RACE favors adding a single multiracial category, arguing that the common experience of having parents of two or more racial categories defines multiracial persons as a distinct group. ${ }^{214}$ They would define multiracial as "[a] person whose parents have origins in two or

category with space for a write-in response. While each application is monoracially race coded for evaluation purposes, there is no policy for reassigning persons who assert plural racial identities. I asked the data entry person how plural racial identities were reclassified, and he responded that he just assigned such persons based on whichever racial identity would improve their chances for admissions. When presscd further on this issue, he stated that, for example, a person identifying as being of White and Mexican descent would be classified Hispanic, while a person of Mexican and Black descent would be classified Black.

213. See supra notes $159-168$ and accompanying text.

214. Hearings, supra note 14, at I07 (testimony of Susan Graham, Executive Director of Project RACE). 
more of the above [American Indian or Alaskan Native, Asian or Pacific Islander, Black, Hispanic, or White] racial and ethnic categories."215 However, if multiracial is defined as having parents with origins in two or more groups, inost African-Annerican and Hispanic persons, and even a significant proportion of White persons in this country, would fall under the multiracial category. ${ }^{216}$

Whether persons of remote mixed ancestry who conceive of themselves monoracially will opt for this category is questionable, especially in an era when preference may be accorded if one identifies as a monoracial minority and when minority group membership is a source of pride and connection for many non-White persons. However, a multiracial category defined thusly raises concerns among some that "a whole host of light-skinned Black Americans [will be] running for the door the minute they have another choice" and that it would result in "a significant diminution in the number of Black Americans who under the present set of circumstances are identified as Black."217 To the extent that the stigmatization of being Black in Annerica would prompt lightskinned Blacks to claim a multiracial identity if such a choice were available could have serious implications for race-based redistricting efforts. Moreover, the flip-side of this phenomenon could find White persons with remote non-White ancestry using such a category to benefit under affirmative action programs.

To allay these concerns, a more restrictive definition could be implemented that would limit use of the single multiracial category to those whose parents identify with different races. This approach would allow multiracial persons to cast off monoracial labels and should decrease the likelihood of inass defection by Blacks and Hispanics or false minority claims by Whites. Moreover, since we have seen that multiracial persons may not necessarily be treated as though they were inembers of monoracial groups, this approach would remove mixed-race persons from monoracial statistics. Consequently, monoracial data would more reliably reflect treatinent of the monoracial groups they purport to represent. In the law firm hiring setting, for example, we would have an idea if minority hiring actually reflects access by monoracial minorities, or if employers prefer mixed-race persons to monoracial minorities.

Yet, although a discrete multiracial category would yield nore reliable monoracial data, we must still consider whether this approach over-

215. Id. at 113 (prepared statement of Susan Graham, Executive Director of Project RACE).

216. Maria P.P. Root, supra note 163, at 9. Estimates of the percentage of African genes distributed among the White population of the United States range from 1 to 5\%. DAvis, supra note 40 , at $2 \lambda$.

217. Hearings, supra note 14, at 273 (prepared statement of Arthur A. Fletcher, Chairperson, U.S. Commission on Civil Rights). 
all improves race data for tracking discrimination. With a single multiracial category, a White/Asian person and a White/Black person would be categorized together. While such persons share the common experience of having parents of different races, we must consider whether this is sufficient reason to treat them as a single racial group. ${ }^{218}$ According to some, the very idea of a multiethmic community is self-contradictory because of the variations inherent in such communities. ${ }^{219}$ Even if there were commonalities in the self-perception of mixed-race persons, it is unlikely these people are perceived by others as racially similar on the basis of their interracial households. Rather, given the internalization of hypodescent, it is possible, if not likely, that the White/Black person would be treated as if she were Black, and the White/Asian person treated as if he were Asian. Given the different stereotypes and relative "success" rates of Blacks and Asians, it is not clear that for purposes of tracking discrimination we would be able to make much use of a single multiracial category.

Thus, if we create a new category that includes mixed-race persons of all backgrounds, we are no closer to being able to reaggregate such data meaningfully. Data that included such a multiracial category would not be comparable with past data collected under the current classification scheme.

By introducing a new measure of incompatibility we not only lose the informational value of comparisons over time, but more importantly, introduction of a single multiracial category would allow employers and other social actors a screen for discriminatory behavior. For example, employers could argue that decreasing numbers of monoracial minority employees was simply the result of multiracial reclassification rather than discriminatory behavior. While such a claim may be legitimate in a particular case, we would be unable to disaggregate a single multiracial category in order to discern those cases where employers were using the multiracial category as a screen for discrimination against particular monoracial minority groups.

This approach would mitigate the arbitrary impact of classifying multiracial persons as monoracial, but would introduce a new arbitrary factor of conflating all mixed-race persons who may be differently treated. Because this disrupts data comparability over time and provides

218. Id. at 101 (prepared statement of Henry Der, National Coalition for an Accurate Count of Asians and Pacific Islanders). See also Michael C. Thomton, Is Multiracial Status Unique? The Personal and Social Experience, in RACIALly MiXed PEOPLE IN AMERICA, supra note 1, at 321 (arguing that, while multiracial people share an ambiguous status, this commonality falls short of the phenotypical or cultural commonality that characterizes monoracial groups, and therefore militates against adopting a single multiracial category on the census).

219. See Hearings, supra note 14, at 168 (testimony of Thomas E. Petri, U.S. Congressman, Wisconsin). 
employers and others with a screen for discriminatory behavior, this solution creates more problems than it solves.

\section{Multiracial Category with Parental Racial Information}

Earlier, I defimed mixed-race persons as those whose parents identify themselves as being of different races. ${ }^{220}$ This definition is consistent with the situation of most persons who identify as mixed-race. Consequently, this definition is consistent with most of those persons whose insistence on subverting attempts at monoracial classification results in the data discrepancy problems I have enumerated. This Section, therefore, evaluates the effect on these problems by creating a multiracial category that requires parental racial identification. ${ }^{221}$

This scheme, like the previous one, would provide a multiracial option in addition to the discrete monoracial categories. Those who choose the multiracial category would be requested to provide the additional information of their parents' racial identification.

Requiring parental racial identification would mitigate any incidents of "defection" from monoracial categories based on remote mixed ancestry, while not denying the opportunity for such persons to assert their self-identity. For example, im a case where a person identifies as multiracial instead of Black, yet identifies her parents as both being Black, we would be able to reaggregate information on such a person with Black data, based on our definition of mixed-race as having parents who identify with different races. Thus, the concerns that lightskinned Blacks would opt for an alternative to Black could be addressed since, to the extent such a phenomenon occured, such persons could be reclassified Black.

More importantly, by having component information, we would be able to determine whether it makes sense to reaggregate mixed-race data, and to do it in a meaningful manner. For example, Black/White persons' employment patterns could be compared against both Black persons' and White persons' employment patterns in order to determine if mixed Black/White persons are treated more as though they were Black or more as though they were White. Moreover, we could find out whether Black/White persons who identify as mixed-race are treated differently than either Black or White persons. In this case, we may determine that reaggregation only undermines both White and Black data.

Therefore, this proposal, rather than creating a hierarchy among Blacks, as some fear, ${ }^{222}$ may allow us to determine if, in fact, there exists

220. See supra Part I.

221. This proposal is advanced by the Association of MultiEthnic Americans ("AMEA"). Hearings, supra note 14 , at 137.

222. See Grillo, supra note 2, at 26. 
a hierarchy among Blacks. The distinction is crucial. Instead of essentializing the situation of all persons of African descent, ${ }^{223}$ such an approach would allow us to determine whether mixed White/Black persons are differently situated from Blacks.

Rather than adversely affecting monoracial minority groups, as some commentators have suggested (for example, assertions that counting people as mixed-race rather than Black will result in decreased social services to Black communities), ${ }^{224}$ by collecting discrete mixedrace data separate from monoracial data, we will not be including among minority groups persons, who because of their appearance, socialization, and access to White culture, may not suffer the same measure of discrimination suffered by monoracial minorities. By distinguishing mixed White/Black persons from Blacks, the impact of discrimination on the latter can be more accurately assessed and resources to remedy discrimination more precisely targeted than under an approach that lumps the two groups together.

We may find, for example, that Black/White mixed-race persons suffer discrimination to a degree commensurate with Blacks who identify as Blacks. Then, instead of merely reclassifying out of habit or erroneously reclassifying such persons as White because that was the race of their mother, we can meaningfully and purposefully reaggregate such data. Moreover, such a system would then give us the flexibility to eschew the hypodescent rule as applied to mixed Asian/Whites if we find that such persons do not experience discriminatory barriers to the same degree as persons identifying as monoracially Asian.

There are, however, significant limitations to the feasibility of implementing this approach. First, this approach presumes that an individual's parents identify monoracially. Given the recency of the increase in race mixing in this country, this presumption would likely be wrong in only a sinall number of cases. However, it does open the door for reinstating official tracking of blood quanta, for once the growing population of mixed-race persons begin having children we would either need to track back through the generations (e.g. grandparents' racial data) or abandon the parental component information collection as more mixed-race persons have parents who are mixed-race themselves. Thus, if we were to implement this approach there is only a limited time

223. As Trina Grillo describes it:

Essentialism is the notion that there is a single woman's, or Black person's, or any other group's, experience that can be described independently from other aspects of the person-that there is an 'essence' to that experience. An essentialist outlook assumes that the experience of being a member of the group under discussion is a stable one, one with a clear meaning, a mcaning constant through time, space, and different historical, social, political, and personal contexts.

Id. at 19. See also generally Harris, supra note 82, at 585 .

224. Grillo, supra note 2 , at 26. 
frame within which such data could be derived. Such a limited time frame may not yield enough trend information to enable meaningful reaggregation decisions to be made. Alternatively, we could adopt a majority rule approach that requires persons with a multiracial and a monoracial parent to identify by the race of the monoracial parent. However, this may open up the kinds of arbitrariness problems that other bright-line reclassification rules have presented. ${ }^{225}$ Second, such an approach presumes compliance im that it would only be workable were multiracial persons willing to list their parents' component races. Those multiracial persons who felt that such an approach was unduly intrusive may decide to check "multiracial" without providing the requested parental component information. In this case, we would have the kinds of problems discussed in the previous section.

In sum, this approach comes further than the sole multiracial category in mitigating the problems I have identified with the current system. First, because it would require parental component information, it would necessarily preclude other-identification, eliminating the discrepancy that arises when both self- and other-reported data are used. Second, it would provide a way to meaningfully reaggregate data by allowing comparisons between mixed-race persons with each of their component racial groups. Third, meaningful reaggregation would promote consistency as reliable standards of reaggregation are instituted across the board.

However, this approach would only be feasible for a limited time frame and it is uncertain whether it would yield the desired data as this approach depends entirely on voluntary compliance. Yet, it is precisely this narrow window of opportunity that calls for the implementation of this approach. With the increasing number of multiracial people, the current system is already obsolete. With a better understanding of what mixed-race status means in terms of our antidiscrimination efforts, our American system of race classification may be temporarily fixed to allow us the time to develop alternative, long-term approaches to confronting the problem of race discrimination in our country.

VII

\section{Locating MrXed-Race IDEntity in Race Consciousness Theory}

This Comment has not evaluated the extent to which race should play a role in policy considerations. Instead, it has taken as a given that federal and local governments will continue to collect race data. In light of the current uses to which those data are put, it has examined the utility of the current methodology for monoracial reassignment within the

225. See supra Part V.B.2.c. 
existing framework of civil rights law. However, a growing number of commentators question whether and to what extent race classification should play a role in policymaking. Some readers may find that by locating my analysis within the boundaries of the existing race classification model, I am implicitly endorsing the current system and its underlying goals and assumptions. With these concerns in mind, I wish to clarify my position on some issues.

The current classification model is flawed in ways other than the mixed-race classification shortcomings I have addressed. As mentioned earlier, it is coming under attack for a number of reasons. Some commentators criticize the current Hispanic classification for its arbitrary delmeation of race and ethnicity which forces most Hispanics to identify racially as White, when in reality this population is largely of mixed indigenous and European ancestry. ${ }^{226}$ Some argue that the United States' relationship with Native Hawaiians has been characterized by the same exploitation and expropriation that characterized U.S. relations with Native Americans, and that Native Hawaiians therefore should be considered as Native Americans. ${ }^{227}$ Others question the presumption that Middle Easterns are White. ${ }^{228}$

It is not necessary for this Comment to address these other shortcomings since the question of whether the current categories should be maintained, redefined, or expanded to include other monoracial groups remams tangential to the issue of monoracial classification of mixedrace persons. As long as the prevailing presumption is that all persons are monoracial, persons asserting plural racial identities will cause the same data accuracy problems regardless of the number of discrete monoracial categories.

However, by offering my analysis withm the framework of the purported goals of Directive No. 15 and its relationship to antidiscrimination law enforcement, I reveal my belief that the current system, while flawed, does allow us to track disparate resource allocation along color limes. I also believe that this is a task worth accomplishing. Therefore, some discussion locating my analysis within the larger debate over racebased classification is in order.

The question of the extent to which race ought to influence regulation has recently come under increasing scrutiny. With the Supreme

226. See generally Toro, supra note 36 , at 120 .

227. See Mililani B. Trask, Historical and Contemporary Hawaiian Self-Determination: A Native Hawaiian Perspective, 8 ARIz. J. INT'L \& CoMp. L. 77, 83 (1991).

228. See Eileen R. Kaufman, A Race by Any Other Name: The Interplay Between Ethnicity, National Origin and Race for Purposes of Section 198I, 28 ARIz. L. Rev. 259, 260-61 (1986) (identifying Syrians, Iraquis, Iranians, Israelis, Egyptians, and Ethiopians among those seeking race discrimination protection under Section 1981). 
Court's decision in Adarand Constructors, Inc. v. Pena ${ }^{229}$ subjecting benign race classifications to strict scrutiny, proposed review of affirmative action programs by Senate Republicans, ${ }^{230}$ the University of California Regents' decision to bar consideration of race in admissions, contracting, and hiring throughout the nine-campus University of California system, ${ }^{231}$ the upcoming California Civil Rights Initiative, which would bar state use of race or gender preferences, ${ }^{232}$ and similar movements across the nation, ${ }^{233}$ there is significant tension between a coinmitment to color-blind ideals and the use of race-conscious means to achieve those ideals.

Traditional civil rights discourse attributes racial disadvantage to prejudice based on race. Because historical attention to race reinforced racial subordination, liberals and progressives located themselves in opposition to ideas of white supremacy by embracing a philosophy of colorblindness that transcended racial classification. ${ }^{234}$ This ideology prizes objective standards of individual merit and strives for universal norms of equal treatment. ${ }^{235}$ Consequently, distinctions based on race are thought repugnant to enlightened society, and differential success is attributed to current and historical discrimination in this country, rather than to superior and inferior racial attributes. ${ }^{236}$

The commitinent to individualisin once represented the articulation of a liberal perspective in opposition to conservative notions of White supremacy. Today, however, proponents of a "strong"color-blind perspective articulate the politically conservative position on race con-

229. 115 S. Ct. 2097 (1995).

230. See, e.g., Affirmative Action Will Be Examined in Senate, Dole Says, N.Y. Times, Feb. 6, 1995 , at A15.

231. See, e.g., Amy Wallace \& Dave Lesher, UC Regents, in Historic Vote, Wipe Out Affirmative Action, L.A. TIMEs, July 21, 1995, at A1.

232. See, e.g., Max Vanzi, Affirmative Action Opponents File Initiative with State Officials, LA. Times, Aug. 8, 1995, at A3.

233. See, e.g., Frank Reeves, Caution Urged on Affirmative Action Cutback, PITtsBurg (Pa.) Post-Gazetre, Feb., 23, 1995, at C1 (reporting on legislation aimed at abolishing Pennsylvania's affirmative action programs); Frances C. Whittelsey, In Suffolk, Affirmative Action Comes Under Attack, N.Y. Times, Aug. 27, 1995, at LI 1 (reporting on attempts to outlaw affirmative action in Suffolk county, New York).

234. Gary Peller, Race Consciousness, 1990 Duke L.J. 758, 761 (1990).

235. Id. at 772-75. This formal color blindness is endorsed by the Supreme Court, most notably in Shaw v. Reno, 509 U.S. 630 (1993). Justice O'Connor, writing for the majority, asserted that "[r]acial classifications of any sort pose the risk of lasting harm to our society. . . [t]hey reinforce the belief, held by too many for too much of our history, that individuals should be judged by the color of their skin." Id. at 657. However, formal color-blind jurisprudence has been widely criticized. See, e.g., Gotanda, supra note 31 (arguing that color-blind jurisprudence reinforces White social, political, and economic advantage).

236. Peller, supra note 233, at 767-69. 
sciousness. ${ }^{237}$ In this more absolute vision of colorblindness, which speaks to the growing numbers of people opposed to affirmative action, race should not matter, period. ${ }^{238}$ Under this view, affirmative action "unjustifiably alter[s] meritocratic standards"2339 since race should be as irrelevant as eye color in the distribution of resources. ${ }^{240}$ Thus, while there is general consensus that race-based discrimination is wrong, ${ }^{241}$ the question of whether we should adopt race-conscious measures to affirmatively dress disparate resource allocation remains controversial.

Even among those who endorse race-conscious measures, there exists debate over the rationale for and the nature of such measures. One response to the controversy over race-based classifications is to argue that they will some day be irrelevant in a color-blind world. The categories should be viewed as temporary and remedial, and it is therefore appropriate to link thein to a backward-looking, corrective justice perspective. ${ }^{242}$ To this end, race conscious measures "are temporary palliatives, not permanent reflections of racial difference."243

Others argue that racial differences should be positively valued in a pluralistic society. From this perspective, the assertion of color-blind norms is really the assertion of White cultural norms. As such, the norms render positive racial differences invisible, perpetuating the legacy of racial oppression and domination in this country. ${ }^{244}$ Race consciousness is therefore appropriate not only to remedy past and current discrimination, but to promote other legitimate and significant government objectives such as seeking non-Whites for social service positions

237. Professor T. Alexander Aleinikoff defines "strong color-blindness" as the view that "race should truly be an irrelevant, virtually unnoticed, human characteristic." T. Alexander Aleinikoff, $A$ Case for Race-Consciousness, 91 Colum. L. REv. 1060, 1078 (1991).

238. See, e.g., Nicholas Lemann, Taking Affirmative Action Apart, N.Y. TnMES MAG., June 11, 1995 , at 36.

239. Aleinikoff, supra note 236, at 1064. See also Morris B. Abram, Affirmative Action: Fair Shakers and Social Engineers, 99 HARv. L. REv. 1312, 1312-13 (1986) (calling for a return to colorblind principles).

240. See Aleinikoff, supra note 236 , at 1076-78.

241. But see Richard A. Epstein, Forbidden Grounds: The Case Against Employment Discrimination LAws 20-77 (1992). Epstein writes that "[i]n a world of free access to open markets, systematic discrimination, even by a large majority, offers little peril to the isolated minority" and that racial discrimination is economically efficient and can improve the ability of businesses to compete. Id. at 32.

242. See Aleinikoff, supra note 236 , at 1064.

243. Rachel F. Moran, Love and a Garden Hoe: Rationality, Romanticism, and Interracial Relationships 2 (1995) (unpublished manuscript, on file with the author).

244. See generally Aleinikoff, supra note 236 (arguing that a norm of color blindness paradoxically supports racial discrimination); Kimberle W. Crenshaw, Foreword: Toward a RaceConscious Pedagogy in Legal Education, 11 NAT'L BLACK LJ. 1 (1988) (discussing the ways in which White norms affect legal education); Peller, supra note 233. 
that deal mostly with minority communities ${ }^{245}$ and encouraging diverse student bodies that facilitate a broader range of discourse. ${ }^{246}$

Where you stand on these issues necessarily affects your stance on the issue of whether and how to classify by race. Under a "strong" color-blind model any race classification perpetuates attention to race. As such, it reinforces ideas of racial difference and forestalls achieving a color-blind society. ${ }^{247}$

Proponents of this perspective may find that my suggestion to collect even more discrete racial data would only exacerbate unwanted attention to racial difference. However, eliciting information on mixedrace persons may also lead to conclusions that this camp would support. We may find the treatment of mixed-race persons so varied that no general assumptions can be made about such persons. On that basis we may realize that there is no rational basis for including them among monoracial statistics. Therefore, as the mixed-race population increases we would be faced with an increasing number of persons who cannot be meaningfully classified. Ultimately, we could be unable to administer race-conscious law and consequently have no alternative but to adopt color-blind institutions. ${ }^{248}$

However, while I have articulated one reason why collecting multiracial data with parental component information may ultimately substantiate adherence to color-blind norms, I should make clear my own view: the color-blind perspective, which sounds nice in theory, is blind to reality. I remain unconvinced that simply ignoring the overwhelming degree to which race shapes our social and institutional interactions will somehow ameliorate the role of race in resource allocation decisions. ${ }^{249}$ Admittedly, there is a certain appeal to the argument that we cannot stop paying attention to race until we stop paying attention to race. ${ }^{250}$ However, this position is rightly rejected, for even if society could be trusted

245. Aleinikoff, supra note 236, at 1065.

246. Moran, supra note 242, at 3. Note that "diversity"--the view that racial and cultural pluralism is a positive good-is distinguished from "tolerance," the view that racial and cultural pluralism are "necessary evils" which should be tolerated. Gotanda, supra note 31, at 53.

247. See Aleinikoff, supra note 236, at 1077-78.

248. See Ford, supra note 42.

249. For a substantive critique of colorblind jurisprudence, see Aleinikoff, supra note 236; Gotanda, supra note 31.

250. This view is echoed in varied writings. Justice Scalia writes that "[t]he difficulty of overcoming the effects of past discrimination is as nothing compared with the difficulty of eradicating from our society the source of those effects, which is the tendency-fatal to a Nation such as oursto classify and judge men and women on the basis of . . . the color of their skin." City of Richmond v. J.A. Croson Co., 488 U.S. 469, 520 (1989) (Scalia, J., concurring in the judgment). Cf. William Van Alstyne's assertion: "[O]ne gets beyond racism by getting beyond it now: by a complete, resolute and credible commitment never to tolerate in one's own life-or in the life or practices of one's government-the differential treatment of other liuman beings by race." William Van Alstyne, Rites of Passage: Race, The Supreme Court, and the Constitution, 46 U. Crr. L. REv. 775, 809 (1979). 
to self-monitor and to cease conscious discrimination, this would not eradicate uuconscious discrimination, ${ }^{251}$ nor would it necessarily eradicate the effects of past discrimination. ${ }^{252}$ In order to monitor and to remedy racially discriminatory behavior, it is essential that we monitor resource distribution by race. Consequently, to the extent that we can agree that as a society we are committed to eradicating both invidious and unconscious racial discrimination, we can also agree on the need to employ racial classifications in order to monitor the extent and effects of race-based discrimination. ${ }^{253}$ I see the collection of multiracial data as improving such efforts.

The collection of multiracial data with component parental information is conducive to the eradication of discrimination whether one believes that race classification should be viewed as temporary, remedial, and a tool for corrective justice, or whether one believes that our colorconscious society will persist and new categories will be crucial in shaping prospective race relations. By exploring the treatment of various mixed-race groups we will be better able to reaggregate such persons into the traditional monoracial component groups that best reflect their treatment by society. Therefore, data accuracy is enhanced to facilitate remedial, corrective justice efforts. In addition, discrete mixed-race data will yield information about how our population is changing. We may find that mixed-race persons are accorded a unique status that counsels continued separate enumeration. Therefore, such an approach also facilitates a forward-looking perspective that positively values diversity.

\section{CONCLUSION}

"Zebra, Halfbreed, Oreo... [w] hether at school or in other parts of the community, Multiracial children are constantly being reminded that they have no official racial identity."254 Given our racialized history and the persistent divisiveness of racial issues, it is not surprising that we

251. Professor Charles Lawrence argues against an intent standard in discrimination, explaining that:

Americans share a coinmon historical and cultural heritage in which racism has played and still plays a dominant role. Because of this shared experience, we also inevitably share many ideas, attitudes, and beliefs that attach significance to an individual's race and induce negative feelings and opinions about nonwhites. To the extent that this cultural belief system has influenced all of us, we are all racists. At the same time, most of us are unaware of our racism. We do not recognize the ways in which our cultural experience has influenced our beliefs about race or the occasions on which those beliefs affect our actions. In other words, a large part of the behavior that produces racial discrimination is influenced by unconscious racial motivation.

Charles R. Lawrence III, The Id, the Ego, and Equal Protection: Reckoning with Unconscious Racism, 39 Stan. L. Rev. 317, 322 (1987) (internal citations omitted).

252. See Aleinikoff, supra note 236, at 1088-89.

253. Rather than dispute the need to classify by race, some critics argue that the question is moot since it is too difficult to accurately classify by race at all. See, e.g., Ford, supra note 42.

254. Hearings, supra note 14, at 161 (prepared statement of Maj. Marvin C. Arnold, Ph.D.). 
tity. Yet, as we struggle with whether and to what extent race does or ought to affect public policy, we cannot afford to continue under the fiction that our nation's people can be easily divided into discrete boxes.

At the very least, the purposes for which we collect race data are undermined by the failure to reclassify mixed-race persons in a consistent and meaningful manner. Consequently, we have no alternative but to question the validity of resource allocation decisions made on the basis of such suspect information. If we are to continue to base resource allocation on the presumption of monoracial categories, we must ensure that the monoracial classification of mixed-race persons is done in a manner that least disrupts the validity of such data. Collection of multiracial data with parental component information may allow us to do this. Moreover, whether one believes that race should not and cannot matter im American society, or whether one believes that it should and does, the collection of multiracial data will give us better information to evaluate the viability of social policies premised on such beliefs.

Finally, by officially recognizing mixed-race status, we will take a step toward dismantling the dividing lines of race. Thus far, we have not been very successful in our attempts to build bridges among our many diverse racial and ethnic communities. We may find, as some have hoped, that mixed-race persons can serve as ambassadors among communities, for mixed-race persons create mixed-race families. My White grandparents, who so easily rejected the idea of a "Jap" grandson, could not find it in themselves to reject the person. My unavoidable existence as a member of their family made their family part Japanese. Not long after I was born, my White grandparents not only accepted me as their grandson, but accepted my Japanese mother as their daughterin-law. My parents' mixed marriage and their mixed children brought together my grandfathers, two men who had fought against each other in World War II, to shake hands and welcome each other as members of the same family.

Instead of ignoring the unique situation of mixed-race persons and dismissing mixed-race identity as a delusion born of efforts to escape stigmatization, we should look instead with an eye toward understanding. Let us expand our ideas of intersectionality to comprehend not only that we each are situated at the intersection of race, gender, socioeconomic status, and countless other facets of personal identity, but also that some of us are at the intersection of different racial identities.

As one commentator has observed, "[t]he wide world that is laid open for people with multiple heritages is a well of potential, centered in a sometimes perilous terrain. The sliding identity that can be so 
difficult at first can become a very powerful tool for peacemakers."25s And as another has noted, multiracial identity may be the "next logical step" in the progression of civil rights by eroding hierarchical conceptions of race through the adoption of "holocentric" racial selves. 256 Rather than being the problem that disrupts tidy racial boxes, it may be possible that mixed-race persons can help us take those boxes apart.

255. Amott, supra note 162 , at 267.

256. G. Reginald Daniel, Beyond Black and White: The New Multiracial Consciousness, in Racially MiXed People in America, supra note 1, at 333, 334 (citations omitted). 
